\title{
CEffect of Silver Nanoparticles Versus Titanium Dioxide Nanoparticles on the Lung of Adult Male Albino Rats: A histological \\ Original and immunohistochemical study
}

Article

\author{
Magdy F. Gawish, Sahar F. Shaban, Sara M. Abdel Aal, Salma S. Shalabi \\ Department of Histology and Cell Biology, Faculty of Medicine, Zagazig University
}

\begin{abstract}
Background: Silver nanoparticles (Ag-Nps) and Titanium dioxide nanoparticles (TiO2-Nps) are well-known nanoproducts. Both of them have many industrial applications. Lung is one of the major target organs for prolonged nanoparticles exposure. Objective: This study was designed to investigate and compare the possible histopathological toxic effect of Ag-Nps \& TiO2Nps on lung and which of them is safer for future using.

Materials \& methods: 54 adult male albino rats were divided into 3 equal groups; GroupI (control group), Group II that subdivided into two subgroups; Subgroup IIa: Ag-Nps group with $(100 \mathrm{mg} / \mathrm{kg} / \mathrm{day})$ daily for 4 successive weeks and Subgroup IIb recovery group left for 4 weeks without injection, Group III that subdivided into two subgroups; Subgroup IIIa: TiO2-Nps group with $(150 \mathrm{mg} / \mathrm{kg} /$ day $)$ for 4 successive weeks and Subgroup IIIb recovery group left for 4 weeks without injection. Lung specimens were processed for light and electron microscope and immunohistochemical expression of caspase-3 and CD-68. Morphometric and statistical analysis were performed.

Results: Group IIa showed collapsed alveoli, others showed ballooned distension and marked thickening of inter-alveolar septa. Extensive cellular infiltration was detected. Group IIIa showed focal areas of collapsed alveoli and thick inter-alveolar septa. Mild cellular infiltrations were observed. Areas of extravasation were detected in the interstitium. Group IIIb showed signs of improvement which is more than group IIb.

Conclusion: exposure to Ag-Nps showed marked alterations on histological structure of lung, which is more than the alteration caused by $\mathrm{TiO} 2-\mathrm{Nps}$; in addition, recovery period was proved to ameliorate these changes better in TiO2-Nps.
\end{abstract}

Received: 17 Apr 2019, Accepted: 20 May 2019

Key Words: Lung, rats, silver nanoparticles, titanium dioxide nanoparticles.

Corresponding Author: Sara M. Abdel Aal, Department of Histology and Cell Biology, Faculty of Medicine, Zagazig University, Egypt, Tel.: +2 01001830969 , E-mail: sara_mma@yahoo.com.

ISSN: 2536-9172, Dec 2018 Vol.2, No.2

\section{INTRODUCTION}

Nanoparticles (Nps) have been known from centuries. The main characteristic of Nps is their size, which is between 1 and $100 \mathrm{~nm}$ in atleast one dimension. This can modify the physicochemical properties of the material as well as create the opportunity for increased uptake and interaction with biological tissues ${ }^{[1]}$.

Nanoparticles have many advantages such as longer shelf-stability, high carrier capacity, and ability to incorporate hydrophilic and hydrophobic drug molecules increase the bioavailability of drugs ${ }^{[2]}$.

Silver nanoparticles (Ag-Nps) are dark brown to gray particles $^{[3]}$. They have unique physicochemical properties including a high electrical and thermal conductivity. AgNps are engineered in various size and shape, it could be spheres, platelets, cubes and rods. Formulations of AgNps with various carrier molecules increase their stability, biocompatibility and versatility ${ }^{[4-6]}$.
There are capped and uncapped Ag-Nps. Capped AgNps is achieved by adding capping agents, which bind to the nanoparticle surface via covalent bonds or by chemical interaction. These capping agents are essential to prevent nanoparticle aggregation and increase the solubility of the nanosystem, and also can be used as a site for bioconjugation of the nanoparticle with important molecules ${ }^{[7,8]}$.

Silver nanoparticles have wide range of applications: air sanitizer sprays, face masks, wet wipes, detergent, soap, shampoo, toothpaste, air filters, vacuum cleaners, washing machines, food storage containers, catheters, orthopedic bone cement, antiseptic sprays, wound dressings, liquid condoms, contraceptive devices and surgical instruments. Other important medical applications of $\mathrm{Ag}$-Nps are drug delivery, antiviral, antimicrobial, and anticancer agents ${ }^{[6,9,10]}$.

Titanium dioxide nanoparticles (TiO2-Nps) occur in different sizes, shapes, chemical compositions and four crystalline polymorphic forms. Naturally exists in anatase, rutile, and brookite ${ }^{[11]}$. 
Titanium dioxide nanoparticles are capable of a wide variety of applications in life science and industry, such as in the productions of paints, coatings, plastics, skin care products, foods as well as in air and water filters. Other important medical applications of $\mathrm{TiO} 2-\mathrm{Nps}$ are excellent antibacterial tools and cytotoxic effects on cancer. TiO2$\mathrm{Nps}$ also share in formation of articulating prosthetic implants $^{[11-16]}$

The size of TiO2-Nps is critical in its toxic effect, the smaller the particles size of $\mathrm{TiO} 2$, the more reactivity and toxicity. These nanoparticles can be absorbed into the body by inhalation, ingestion and dermal penetration due to their small size. The heavy usage of TiO2-Nps in industry increases the possible risk association with their environmental exposure ${ }^{[17,18]}$.

According to previous authors ${ }^{[19]}$ silver $(\mathrm{Ag})$ and titanium dioxide (TiO2) nanoparticles are well-known nanoproducts. Both have common manufacturing applications such as in cosmetics, water filters, air conditioning filters and food industry. Medically they are both used as antifungal, antimicrobial and in treatment of cancer.

The smaller sized nanoparticles were found to be more toxic, compared with bigger nanoparticles size. However, the particle size is not the only factor that determines particle toxicity. Other important factors are the synthesis procedure, and the presence or not of capping agents ${ }^{[20,21]}$.

With the increasing utilization of $\mathrm{Nps}$, the general population has a greater risk of exposure through occupational environment and consumer products in daily life. This exposure may occur over several phases of the lifespan of the Ag-Nps, from synthesis and manufacturing, distribution, end-product use and end-of-life disposal of everyday consumer products ${ }^{[22-24]}$.

According to previous authors ${ }^{[25]}$ reported that Ag-NPs accumulate within several targeted organs including liver, lung, spleen and brain.

Many in vitro studies revealed that $\mathrm{Ag}-\mathrm{Nps}$ induce apoptosis, which is associated principally with caspase-3 activity. TiO2-Nps has shown to cross the cell membrane, produce oxidative stress, cause inflammation, damage DNA, and cause apoptosis ${ }^{[11,26,27,28]}$.

The aim of the present study is to investigate and compare the possible histopathological toxic effect of two metal engineered Nps (Ag-Nps\& TiO2-Nps) on lung and which of them supposed to be safer for future using.

\section{MATERIALS AND METHODS}

\section{Chemicals}

\section{Silver nanoparticles (Ag-Nps):}

Silver nanopowder (Chemical Abstracts Service number "CAS-No. 7440-22-4" in poly vinyl pyrrolidone [PVP] as dispersant) with a particle size less than $100 \mathrm{~nm}$ contain $99.9 \%$ trace metals basis. It was purchased from Sigma-Aldrich Chemicals, Cairo, Egypt.

\section{Titanium dioxide nanoparticles:}

Titanium dioxide nanoparticles were synthesized at the laboratory of Faculty of Science Zagazig University.

\section{Synthesis of TiO2-Nps:}

Titanium dioxide nanoparticles were synthesized using a Sol-gel method ${ }^{[29]}$. The used procedure was as following:

- Solution A: $15 \mathrm{ml}$ of titanium isopropoxide added to $45 \mathrm{ml}$ of absolute ethanol at volume ratio (1:3) under continuous stirring for 30 minute until a homogenous white yellow solution produced.

- Solution B: $15 \mathrm{ml}$ of doubly distilled water added to $60 \mathrm{ml}$ of absolute ethanol at volume (1:4), Nitric acid (HNO3) was added drop wise until adjacentment of the solution $\mathrm{pH}$ to be (1) "acidic solution" to restrict the hydrolysis process of the solution.

- The gel preparation process started when both solutions $\mathrm{A} \& \mathrm{~B}$ were mixed together under vigorous stirring for $2 \mathrm{~h}$.

- The gel dried at 80- in water path for $1 \mathrm{~h}$ until most ethanol evaporated after that the produced mixture dried overnight at an oven at 80-.

- Then the dry gel was calcinated at $500^{\circ} \mathrm{C}$ for $5 \mathrm{hrs}$ were subsequently carried out to obtain desired $\mathrm{TiO} 2$ nano-powder.

\section{Animals}

This study was carried out on 54 adult male albino rats with average weight of 180-200 gm. They were obtained from the Animal House at Faculty of Medicine, Zagazig University. Throughout the duration of the experiment, rats were housed in room temperature with normal light/ dark cycles. They were allowed ad-libitum access to food and water. Rats were acclimatized to their environment for one week before starting the experiment. All experimental procedures were performed in accordance with the guidelines of the Institutional Animal Care and Use Committee and accepted by Faculty of Medicine, Zagazig University.

Nanoparticle characterization 
To study the particles size and morphology, the aqueous dispersion of the nanoparticles was drop-cast onto a carbon- coated copper $\operatorname{grid}^{[30,31]}$.

The grid was air dried at room temperature and visualized using JEOL JEM 2100 Transmission Electron Microscope (Jeol Ltd, Tokyo, Japan) at Electron Microscope Research Laboratory (EMRL) of Faculty of Agricultural El Mansoura University, Egypt. (Fig. 1:AgNps \& 2:TiO2-Nps)

\section{Experimental procedure}

The rats were divided into 3 equal groups as following:

Group I (control group): included 18 rats, further subdivided into two equal subgroups ( 9 rats each):

\section{- Subgroup Ia (negative control group):}

Rats received no treatment for 4 weeks.

\section{- Subgroup Ib (positive control group):}

Rats received intraperitoneal injection of $1 \mathrm{ml}$ saline solution daily for 4 successive weeks. The saline represented both silver and titanium dioxide nanoparticles's solvent.

Group II (Silver nanoparticles injected group): included 18 rats that further subdivided into two equal subgroups ( 9 rats each):

- Subgroup IIa: received Ag-Nps intraperitoneally $(100 \mathrm{mg} / \mathrm{kg} /$ day) suspended in $1 \mathrm{ml}$ saline solution daily for 4 successive weeks. $100 \mathrm{mg}$ Ag-Nps dispersed in $5 \mathrm{ml}$ saline and each rat received $20 \mathrm{mg}$ Ag-Nps in $1 \mathrm{ml}$ saline everyday according to their weight $^{[32]}$.

- Subgroup IIb (recovery group): received Ag-Nps as group II a, then left for further 4 weeks after AgNps injection without any further injection ${ }^{[33]}$.

Group III (Titanium dioxide nanoparticles injected group): included 18 rats that further subdivided into two equal subgroups ( 9 rats each):

- Subgroup IIIa: will receive intraperitoneal injection of TiO2-Nps $(150 \mathrm{mg} / \mathrm{kg} /$ day $)$ suspended in $1 \mathrm{ml}$ saline solution daily for 4 successive weeks. 150 $\mathrm{mg}$ TiO2-Nps dispersed in $5 \mathrm{ml}$ saline and each rat received $30 \mathrm{mg}$ TiO2-Nps in $1 \mathrm{ml}$ saline every day according to their weight ${ }^{[34]}$.

- Subgroup IIIb (recovery group): received intraperitoneal injection of TiO2-Nps as group III a, then left for further 4 weeks after TiO2-Nps injection without any further injection ${ }^{[35]}$.
After 4 weeks rats of injected groups (Subgroup IIa and IIIa) and control group were anaesthetized with 50mg/ $\mathrm{kg}$ body weight of sodium phenobarbital through intraperitoneal injection. After 8 weeks rats of recovery groups were anaesthetized as before ${ }^{[36]}$. The thoracic cages were opened; and their lungs were dissected out and processed for light and electron microscopic examination.

\section{Light microscope study}

Specimens for light microscopy were fixed in $10 \%$ saline formalin (buffered) and processed to prepare $5-\mu \mathrm{m}-$ thick paraffin sections for:

(1) Haematoxylin\&Eosin (H\&E) $\operatorname{stain}^{[37]}$.

(2) Immunohistochemical stain:

Immunostaining was performed using the avidinbiotin-peroxidase technique for detection of caspase-3 (Rabbit monoclonal antibody purchased from Lab Vision Laboratories (Cat.\#: 1475-1) at dilution of 1:100) as a marker for apoptosis and CD-68 (Mouse monoclonal antibody purchased from Novocastra labs, UK, at a dilution of 1:20) as a marker for alveolar macrophages.

Paraffin sections of the lung were incubated with biotinylated antimouse antibody (diluted $1: 200$ ) and the avidin biotin-conjugated peroxidase complex (VectorLab. Inc., USA). The reaction was developed with $0.05 \%$ diaminobenzidine (DakopattsGlostrup, Denmark) as the substrate for peroxidase; finally, the slides were counterstained with Meyer's hematoxylin $)^{[38]}$. The cytoplasmic site of the reaction stained brown whereas the nuclei appeared blue. The specificity of the immunereaction was tested by replacing the primary antiserum with phosphate-buffered saline as a negative control ${ }^{[39]}$.

\section{Electron microscope study}

Specimens for electron microscopy were immediately fixed in $2.5 \%$ phosphate-buffered glutaraldehyde $(\mathrm{pH}$ 7.4), post fixed in $1 \%$ osmium tetroxide in the same buffer at $4{ }^{\circ} \mathrm{C}$, dehydrated and embedded in epoxy resin. Ultrathin sections were obtained (Leica ultracut UCT), stained with uranyl acetate and lead citrate ${ }^{[40]}$, examined and photographed using (JEOL JEM 2100 transmission electron microscope; Jeol Ltd, Tokyo, Japan) at Electron Microscope Research Laboratory (EMRL) of Faculty of Agricultural El Mansoura University, Egypt.

\section{Morphomertic study:}

Serial sections with H\&E and immunohistochemical staining were morphometrically analyzed at department of Histology, Faculty of medicine- Zagazig University, using Fiji image $\mathrm{J}(1.51 \mathrm{n}, \mathrm{NIH}, \mathrm{USA})$ program for measurement thickness of inter-alveolar septa and optical density of both 
caspase-3 and CD-68 immune reactions.

\section{Statistical analysis:}

The obtained data from morphometrical analysis ( thickness of interalveolar septa and optical density of immunohistochemical-stained sections,) were expressed as mean $\pm \mathrm{SD}$ (standard deviation) and subjected to oneway analysis of variance (ANOVA) using Statistical Package for the Social Sciences (SPSS) version 16.0 (Chicago,USA).

ANOVA was used for comparison between different groups (more than two groups), with $P$ value less than 0.05 (the level of significance). Least significant difference (LSD) was used to find the statistical difference between the groups when ANOVA was statistically significant $(P$ value $<0.05)$.

\section{RESULTS}

\section{Histopathological results:}

\section{(1) Light microscope results:}

Examination of the H\&E-stained sections of the control group revealed normal histological structure of the lung. Rounded or polygonal alveoli and alveolar sacs separated with thin interalveolar septa. Alveoli were lined by type I pnemocytes with flat nuclei and type II pneumocytes with rounded nuclei. Apparent small bronchiole and thin walled blood vessel were also seen Terminal bronchioles were lined by simple cuboidal ciliated epithelium with underlying few layers of smooth muscles and thin walled blood vessels were also demonstrated (Figure $3 \mathrm{~A}-\mathrm{C}$ ). Immunohistochemical-stained sections of caspase-3 showed weak positive cytoplasmic immunoreaction in few alveolar epithelial cells (Figure 3D). Immunohistochemicalstained sections of CD-68 showed few cells with weak positive cytoplasmic immunoreaction in cells of inter alveolar septa (Figure 3E).

Examination of the Ag-Nps injected group showed marked histological changes; most of alveoli were collapsed with marked thickening of their inter-alveolar septa, others showed ballooned distension. Extensive cellular infiltration was detected peri-bronchiolar, around thickened blood vessel and in the interstitium. Exudation in the interstisium was observed. Terminal bronchioles exhibited vacuolated epithelium, detached cells in their lumina and were surrounded by cellular infiltration. Thickened wall blood vessels were surrounded by a heavily cellular infiltration (Figure $4 \mathrm{~A}-\mathrm{C}$ ). Immunohistochemical-stained sections of caspase-3 showed strong positive cytoplasmic immunoreaction in many alveolar epithelial cells those of inter alveolar septa (Figure 4D) .Immunohistochemicalstained sections of CD-68 showed many cells with strong positive cytoplasmic immunoreaction in between alveolar cells and inter alveolar septa (Figure 4E).

The specimens of H\&E-stained sections of the $\mathrm{Ag}$ Nps recovery group revealed slight improvement. They revealed focal areas of collapsed alveoli separated by thick inter-alveolar septa and others were patent with thin inter-alveolar septa. Bronchioles appeared with detached epithelial cells. Also, thick wall blood vessels were clarified. Cellular infiltrations around both blood vessels and bronchioles were still observed (Figure 5A). Immunohistochemical-stained sections revealed moderate positive caspase-3 cytoplasmic immunoreaction in some alveolar epithelium and cells of inter alveolar septa (Figure $5 \mathrm{~B}$ ) and moderate positive CD-68 cytoplasmic immunoreaction in cells of the inter-alveolar septa and inbetween alveolar cells (Figure $5 \mathrm{C}$ ).

On the other hand, examination of the TiO2-Nps injected group showed moderate focal histological changes when compared with control one. H\&E-stained sections revealed most of alveoli were apparently normal with thin septa and few areas with thick septa were detected. Areas of extravasation were detected in the interstitium .Mild cellular infiltrations were observed around both blood vessels and bronchioles .Bronchioles lined with simple cuboidal epithelium with no detachment. (Figure $6 A \& B)$. Immunohistochemical stained sections revealed mild positive cytoplasmic immunoreaction for caspase-3 in some alveolar cells and interstitial cells (Figure 6C) and Mild positive cytoplasmic immunoreaction for CD-68 in some alveolar cells and in cells of inter alveolar septa (Figure 6D).

Examination of the TiO2-Nps recovery group showed apparently normal histological architecture. H\&E-stained sections revealed that most of alveoli were normal with thin inter-alveolar septa. Minimal cellular infiltration around blood vessels and bronchioles was demonstrated (Figure 7A). Immunohistochemical-stained sections revealed minimal positive cytoplasmic immunoreaction for caspase-3 in few alveolar epithelial cells and in few cells of interstitium (Figure 7B) and minimal positive cytoplasmic immunoreaction for CD-68 in few alveolar epithelial cells and in few cells of inter alveolar septa were seen (Figure 7C).

\section{(2) Electron microscope results}

Ultrathin sections of the control group revealed Alveoli lined by pneumocytes type I with flat nucleus with attenuated cytoplasm and pneumocytes type II with lamellar bodies were seen. Thin inter-alveolar septum containing interstitial cells was detected .pneumocytes type II appeared with euchromatic nuclei, numerous membrane bounded lamellar bodies in their cytoplasm and obvious microvilli on their surfaces (Figure 8A \& B). The blood air barrier with attenuated cytoplasm of type I pneumocytes, fused basal lamina and the cytoplasm of the capillary 
endothelial cells were clarified (Figure 8C).

Examination of the ultrathin sections of the Ag-Nps injected group revealed multiple pneumocytes type II with irregular and heterochromatic nuclei. Most of their lamellar bodies appeared distorted and irregular variable sized vacuoles were also seen. Thick interstitium appeared with different inflammatory cells, one of them has large kidney shaped nucleus, another with large nucleus surrounded by thin rim of cytoplasm. Cells with lobulated nuclei within blood capillary were also noticed (Figure 9 A\&B). Deformed blood air barrier was formed of irregular cytoplasm of pneumocytes type I, fused basal lamina of pneumocte type I and endothelial cell and cytoplasm of the capillary endothelial cell (Figure 9 C).

Ultrastructural examination of the lung of the Ag-Nps recovery group revealed some improvement. Thick septa containing few interstisial cells and blood capillaries. Pneumocyte type II appeared with heterochromatic nucleus and distorted lamellar bodies. Microvilli appeared on its surfaces (Figure A\&B). Blood air barrier with some irregularity of cytoplasm of type I pneumocytes, fused basal lamina and the cytoplasm of the capillary endothelial cells were clarified (Figure $10 \mathrm{C}$ ).

On the other hand, examination of the ultrathin sections of the TiO2-Nps injected group showed moderate changes when compared with control one. The sections showed
Pneumocyte type II appeared with empty lamellar bodies and microvilli on its surface. Intra-alveolar extravasation of red blood cells was seen (Figure $11 \mathrm{~A}$ ). nearly normal blood air barrier was observed formed of attenuated cytoplasm of type I pneumocyte, fused basal lamina of both cells and cytoplasm of endothelial cell of alveolar capillaries (Figure $11 \mathrm{~B}$ ).

Examination of the ultrathin sections of the TiO2Nps recovery group showed nearly normal structures. Apparently normal patent alveoli with relatively thin inter-alveolar septa containing interstitial cells and blood capillaries. Pneumocyte type II appeared with euchromatic nucleus, prominent nucleolus, lamellar bodies and microvilli on its surface (Figure $12 \mathrm{~A} \& \mathrm{~B}$ ). A nearly normal blood air barrier was observed with type I pneumocyte attenuated cytoplasm, fused basal lamina of both cells (type I \& endothelium) and cytoplasm of endothelial cell of alveolar capillaries. Also, type I pneumocyte was observed with euchromatic nucleus (Figure $12 \mathrm{C}$ ).

\section{Morphometric results:}

Our Statistical analysis of the mean values of thickness of the inter-alveolar septa, optical density of caspase-3 immunoreactionand and optical density of CD-68 immunoreaction using ANOVA test were summarized in Tables 1, $2 \& 3$. Comparisons between all studied groups using LSD statistically were summarized in Tables $4,5 \& 6$.

Table 1: Thickness of the interalveolar septa $(\mu \mathrm{m})$ in different groups by one-way ANOVA test:

\begin{tabular}{lccccccc}
\hline \multirow{2}{*}{ Parameter } & Control & $\begin{array}{l}\text { Silver injected } \\
\text { Subgroup IIa }\end{array}$ & $\begin{array}{c}\text { Silver recovery } \\
\text { Subgroup IIb }\end{array}$ & $\begin{array}{l}\text { Titanium injected } \\
\text { Subgroup IIIa }\end{array}$ & $\begin{array}{l}\text { Titanium recovery } \\
\text { Subgroup IIIb }\end{array}$ & F & P \\
\cline { 2 - 5 }$n$ & Mean \pm SD & Mean \pm SD & Mean \pm SD & Mean \pm SD & Mean \pm SD & & \\
\hline $\begin{array}{l}\text { Thickness of } \\
\text { the interalveolar } \\
\text { septum }(\mu \mathrm{m})\end{array}$ & $5.07 \pm 1.4$ & $26.4 \pm 8.12$ & $20.23 \pm 6$ & $15.92 \pm 3.2$ & $7.6 \pm 1.1$ & 40.76 & $<0.001^{* *}$ \\
\hline
\end{tabular}

Values are expressed as mean \pm standard deviation (SD); the ranges are demonstrated; **: highly significant difference $P$ value $(P<0.001)$.

Table 2: Optical density to caspase-3 immuno-reaction in different groups by one-way ANOVA test:

\begin{tabular}{lccccccc}
\hline \multirow{2}{*}{ Parameter } & Control & $\begin{array}{l}\text { Silver injected } \\
\text { Subgroup IIa }\end{array}$ & $\begin{array}{c}\text { Silver recovery } \\
\text { Subgroup IIb }\end{array}$ & $\begin{array}{l}\text { Titanium injected } \\
\text { Subgroup IIIa }\end{array}$ & $\begin{array}{c}\text { Titanium recovery } \\
\text { Subgroup IIIb }\end{array}$ & F & P \\
\cline { 2 - 5 } & Mean \pm SD & Mean \pm SD & Mean \pm SD & Mean \pm SD & Mean \pm SD & & \\
\hline $\begin{array}{l}\text { Optical density of } \\
\text { immune reaction } \\
\text { to caspase-3 }\end{array}$ & $1.11 \pm 0.33$ & $9.1 \pm 1.6$ & $7.45 \pm 1.3$ & $6.954 \pm 0.99$ & $1.49 \pm 0.46$ & 154.2 & $<0.001^{* *}$ \\
\hline
\end{tabular}

Values are expressed as mean \pm standard deviation (SD); the ranges are demonstrated; **: highly significant difference $P$ value $(P<0.001)$.

Table 3: Optical density to CD-68 immuno-reaction in different groups by one-way ANOVA test:

\begin{tabular}{lccccccc}
\hline \multirow{2}{*}{ Parameter } & Control & $\begin{array}{l}\text { Silver injected } \\
\text { Subgroup IIa }\end{array}$ & $\begin{array}{c}\text { Silver recovery } \\
\text { Subgroup IIb }\end{array}$ & $\begin{array}{l}\text { Titanium injected } \\
\text { Subgroup IIIa }\end{array}$ & $\begin{array}{c}\text { Titanium recovery } \\
\text { Subgroup IIIb }\end{array}$ & F & P \\
\cline { 2 - 5 } & Mean \pm SD & Mean \pm SD & Mean \pm SD & Mean \pm SD & Mean \pm SD & & \\
\hline $\begin{array}{l}\text { Optical density of } \\
\begin{array}{l}\text { immune reaction } \\
\text { to CD-68 }\end{array}\end{array}$ & $1.2 \pm 0.4$ & $8.08 \pm 1.98$ & $6.8 \pm 1.6$ & $5.9 \pm 1.4$ & $1.77 \pm 0.36$ & 36.35 & $<0.001^{* *}$ \\
\hline
\end{tabular}

Values are expressed as mean \pm standard deviation (SD); the ranges are demonstrated; **: highly significant difference $P$ value $(P<0.001)$. 
Table 4: The least significant difference of thickness of the interalveolar septum $(\mu \mathrm{m})$ between all studied groups:

\begin{tabular}{|c|c|c|c|c|c|}
\hline & Control & $\begin{array}{l}\text { Silver injected } \\
\text { Subgroup IIa }\end{array}$ & $\begin{array}{l}\text { Silver recovery } \\
\text { Subgroup IIb }\end{array}$ & $\begin{array}{l}\text { Titanium injected } \\
\text { Subgroup IIIa }\end{array}$ & $\begin{array}{l}\text { Titanium recovery } \\
\text { Subgroup IIIb }\end{array}$ \\
\hline Control & & $<0.001 * *$ & $<0.001 * *$ & $<0.001 * *$ & $0.764 \mathrm{~ns}$ \\
\hline $\begin{array}{l}\text { Silver injected } \\
\text { Subgroup IIa }\end{array}$ & $<0.001^{* *}$ & & $0.0464 *$ & $<0.001 * *$ & $<0.001 * *$ \\
\hline $\begin{array}{l}\text { Silver recovery } \\
\text { Subgroup IIb }\end{array}$ & $<0.001^{* *}$ & $0.0464 *$ & & $0.28 \mathrm{~ns}$ & $<0.001 * *$ \\
\hline $\begin{array}{l}\text { Titanium injected } \\
\text { Subgroup IIIa }\end{array}$ & $<0.001 * *$ & $<0.001 * *$ & $0.28 \mathrm{~ns}$ & & $0.003^{*}$ \\
\hline $\begin{array}{l}\text { Titanium recovery } \\
\text { Subgroup IIIb }\end{array}$ & $0.764 \mathrm{~ns}$ & $<0.001 * *$ & $<0.001 * *$ & $0.003 *$ & \\
\hline
\end{tabular}

**: highly significant

$*$ : Significant

ns: Nonsignificant

Table 5: The least significant difference of optical density of immune reaction to caspase-3 between all studied groups:

\begin{tabular}{|c|c|c|c|c|c|}
\hline & Control & $\begin{array}{l}\text { Silver injected } \\
\text { Subgroup IIa }\end{array}$ & $\begin{array}{l}\text { Silver recovery } \\
\text { Subgroup IIb }\end{array}$ & $\begin{array}{l}\text { Titanium injected } \\
\text { Subgroup IIIa }\end{array}$ & $\begin{array}{l}\text { Titanium recovery } \\
\text { Subgroup IIIb }\end{array}$ \\
\hline Control & & $<0.001 * *$ & $<0.001 * *$ & $<0.001 * *$ & $0.919 \mathrm{~ns}$ \\
\hline $\begin{array}{l}\text { Silver injected } \\
\text { Subgroup IIa }\end{array}$ & $<0.001^{* *}$ & & $0.006^{*}$ & $<0.001 * *$ & $<0.001^{* *}$ \\
\hline $\begin{array}{l}\text { Silver recovery } \\
\text { Subgroup IIb }\end{array}$ & $<0.001^{* *}$ & $0.006^{*}$ & & $0.809 \mathrm{~ns}$ & $<0.001^{* *}$ \\
\hline $\begin{array}{l}\text { Titanium injected } \\
\text { Subgroup IIIa }\end{array}$ & $<0.001^{* *}$ & $<0.001 * *$ & $0.809 \mathrm{~ns}$ & & $<0.001 * *$ \\
\hline $\begin{array}{l}\text { Titanium recovery } \\
\text { Subgroup IIIb }\end{array}$ & $0.919 \mathrm{~ns}$ & $<0.001 * *$ & $<0.001^{* *}$ & $<0.001 * *$ & \\
\hline
\end{tabular}

**: highly significant

$*$ : Significant

ns: Nonsignificant

Table 6: The least significant difference of optical density of immune reaction to CD-68 between groups:

\begin{tabular}{|c|c|c|c|c|c|}
\hline & Control & $\begin{array}{l}\text { Silver injected } \\
\text { Subgroup IIa }\end{array}$ & $\begin{array}{l}\text { Silver recovery } \\
\text { Subgroup IIb }\end{array}$ & $\begin{array}{l}\text { Titanium injected } \\
\text { Subgroup IIIa }\end{array}$ & $\begin{array}{l}\text { Titanium recovery } \\
\text { Subgroup IIIb }\end{array}$ \\
\hline Control & & $<0.001 * *$ & $<0.001 * *$ & $<0.001 * *$ & $0.7853 \mathrm{~ns}$ \\
\hline $\begin{array}{l}\text { Silver injected } \\
\text { Subgroup IIa }\end{array}$ & $<0.001 * *$ & & $0.0119 *$ & $<0.001 * *$ & $<0.001 * *$ \\
\hline $\begin{array}{l}\text { Silver recovery } \\
\text { Subgroup IIb }\end{array}$ & $<0.001 * *$ & $0.0119 *$ & & $0.5495 \mathrm{~ns}$ & $<0.001 * *$ \\
\hline $\begin{array}{l}\text { Titanium injected } \\
\text { Subgroup IIIa }\end{array}$ & $<0.001 * *$ & $<0.001 * *$ & $0.5495 \mathrm{~ns}$ & & $<0.001 * *$ \\
\hline $\begin{array}{l}\text { Titanium recovery } \\
\text { Subgroup IIIb }\end{array}$ & $0.7853 \mathrm{~ns}$ & $<0.001 * *$ & $<0.001 * *$ & $<0.001 * *$ & \\
\hline
\end{tabular}

**: highly significant

* : Significant

ns: Nonsignificant 


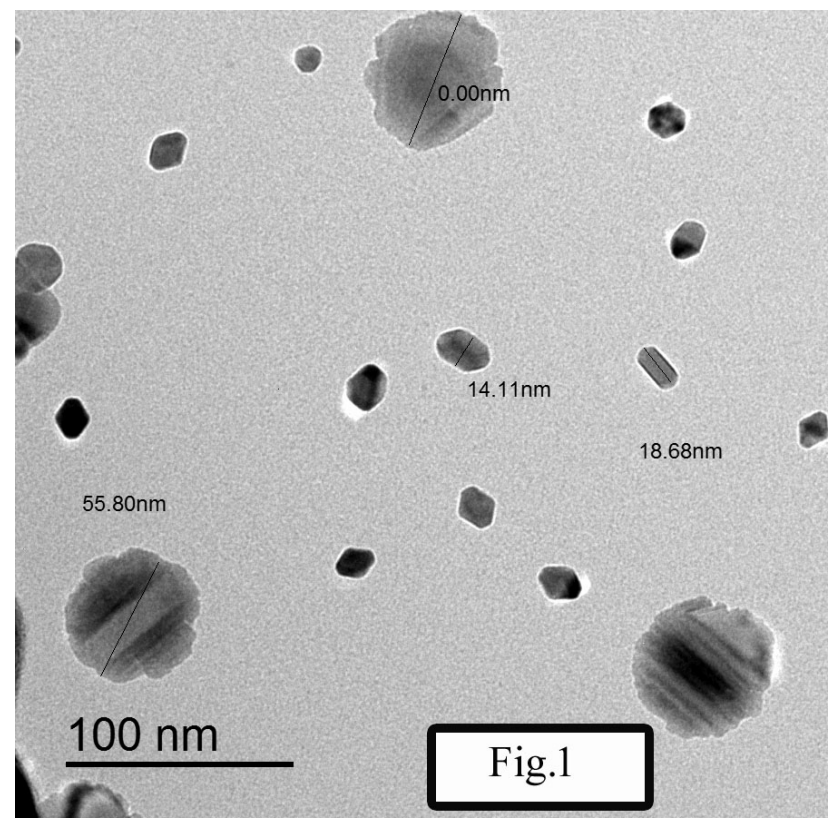

Fig. 1: An electron micrograph showing average diameters of Ag-Nps used in the present study.

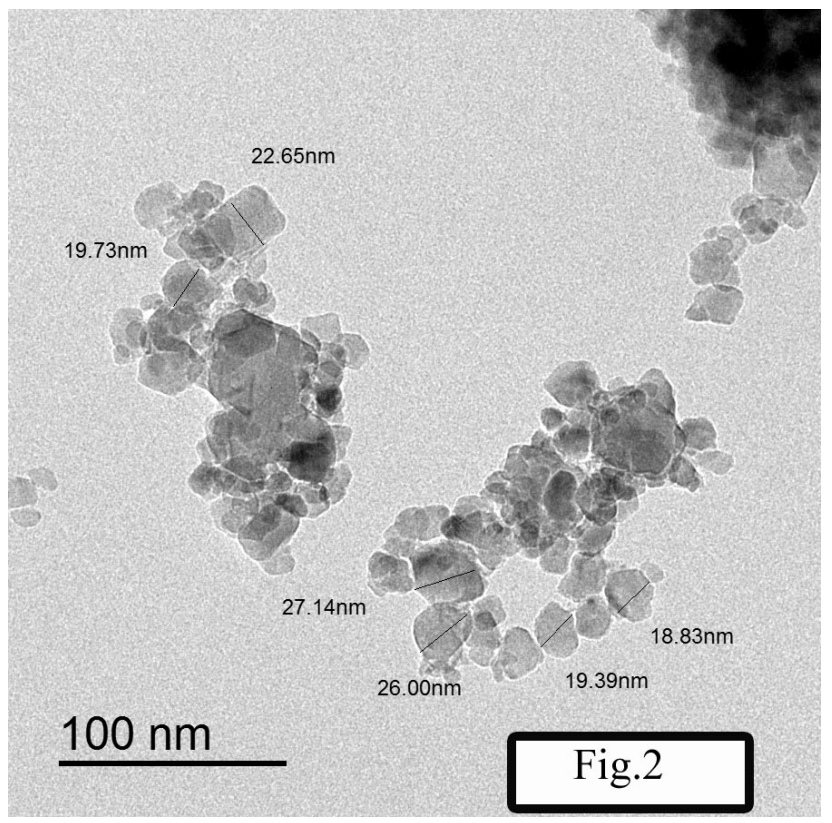

Fig. 2: An electron micrograph showing average diameters of TiO2-Nps used in the present study.

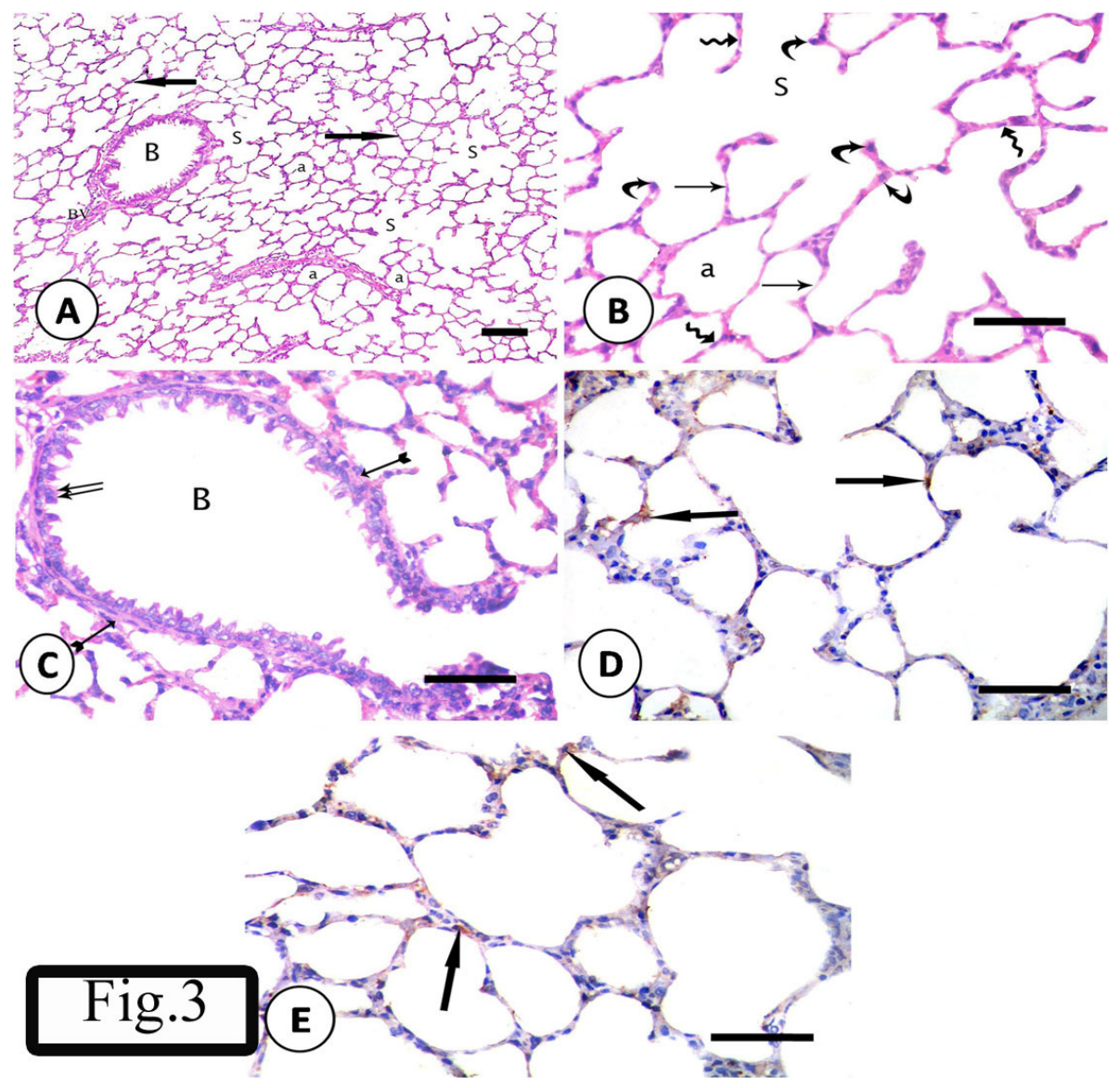

Fig. 3: A photomicrograph of sections in the lung from control group. A) General architecture of the lung; rounded or polygonal alveoli (a), alveolar sacs (S) and thin inter-alveolar septa (arrow).Apparent small bronchiole (B) and thin walled blood vessel (BV) are also seen (H\&E, $100 \times$, scale bar $50 \mu \mathrm{m}$ ). B) Alveolar sacs (S) and alveoli (a) with thin inter-alveolar septa (arrow). Their lining epithelium is composed of pneumocytes type I with flat nuclei (zigzag arrow) and pneumocytes type II with rounded nuclei (curved arrow) (H\&E, x400, scale bar $40 \mu \mathrm{m})$.C) A terminal bronchiole (B)lined by simple cuboidal ciliated epithelium (double arrows) and surrounded by few layers of smooth

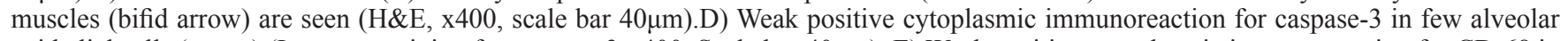
epithelial cells (arrow) (Immune-staining for caspase- $3 \times 400$, Scale bar $40 \mu \mathrm{m}$ ). E) Weak positive cytoplasmic immunoreaction for CD-68 in few cells of inter-alveolar septa (arrow) (CD-68 immune-staining $\times 400$, Scale bar $40 \mu \mathrm{m})$. 


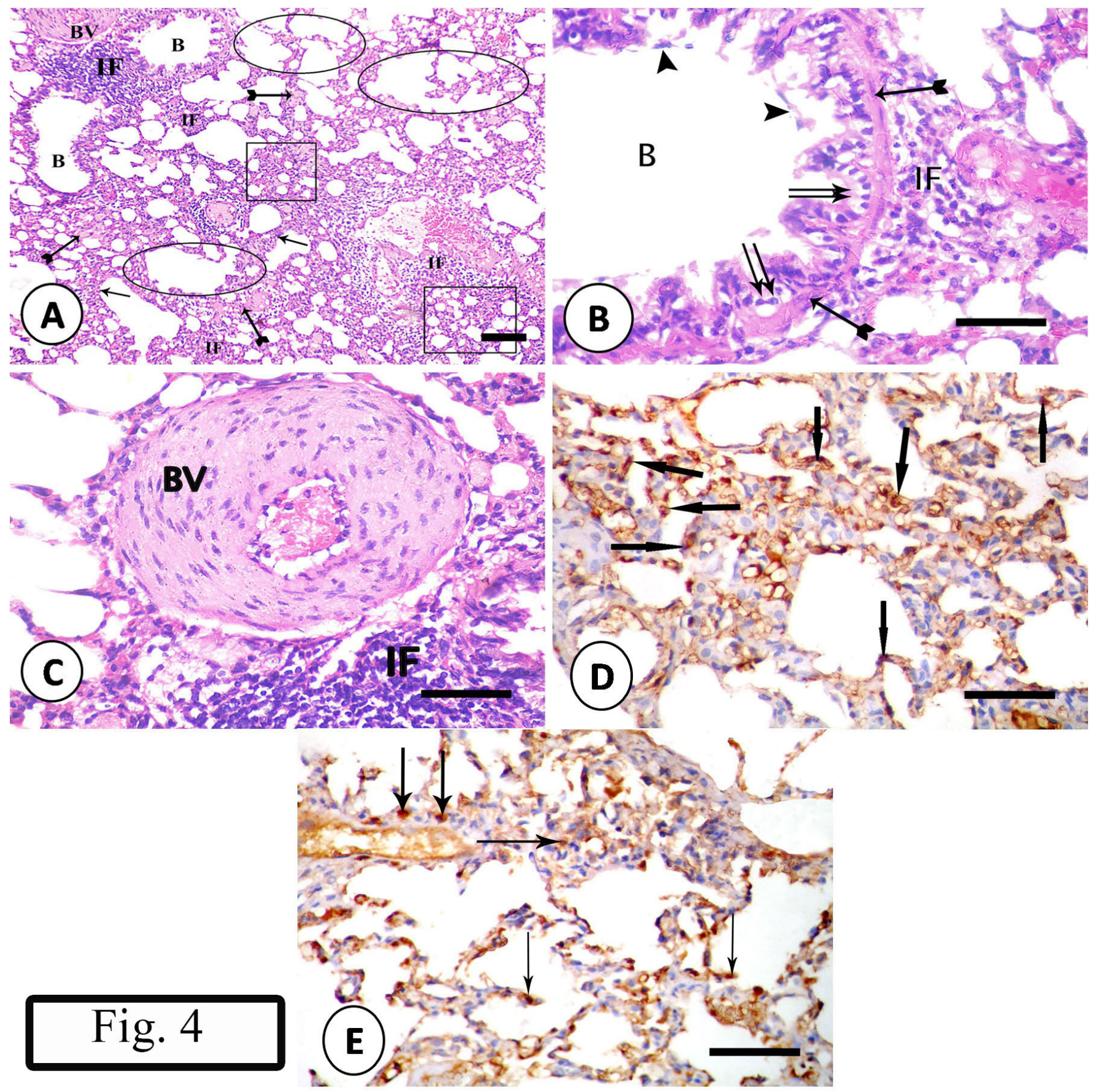

Fig. 4: A photomicrograph of sections in the lung from Ag-Nps injected group. A) Collapsed alveoli (square) and thickening of inter-alveolar septa (arrow). Ballooned distension in other alveoli (ellipsoid) is noticed. Extensive cellular infiltration (IF) is detected peri-bronchiolar (B), around thickened blood vessel (BV) and in the interstitium. Exudation in the interstisium (bifid arrow) is observed (H\&E, x100, scale bar 50 $\mu \mathrm{m})$. B) A terminal bronchiole (B), with vacuolated epithelium (double arrow) with underlaying muscle layer (bifid arrow) and surrounded

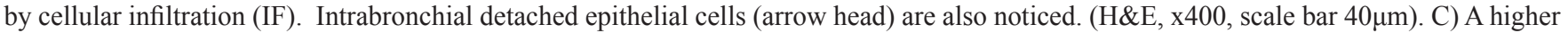

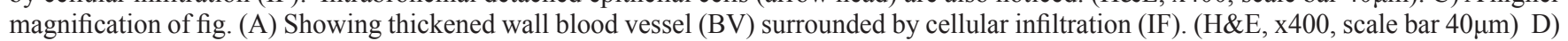
Strong positive caspase-3 cytoplasmic immunoreaction in many alveolar epithelial cells and those of inter alveolar septa (arrow) (Immunestaining for caspase-3 $\times 400$, Scale bar $40 \mu \mathrm{m})$.E) strong positive CD-68 cytoplasmic immunoreaction in many cells between alveolar cells and inter alveolar septa (arrow) (CD-68 immune-staining $\times 400$, Scale bar $40 \mu \mathrm{m})$ 


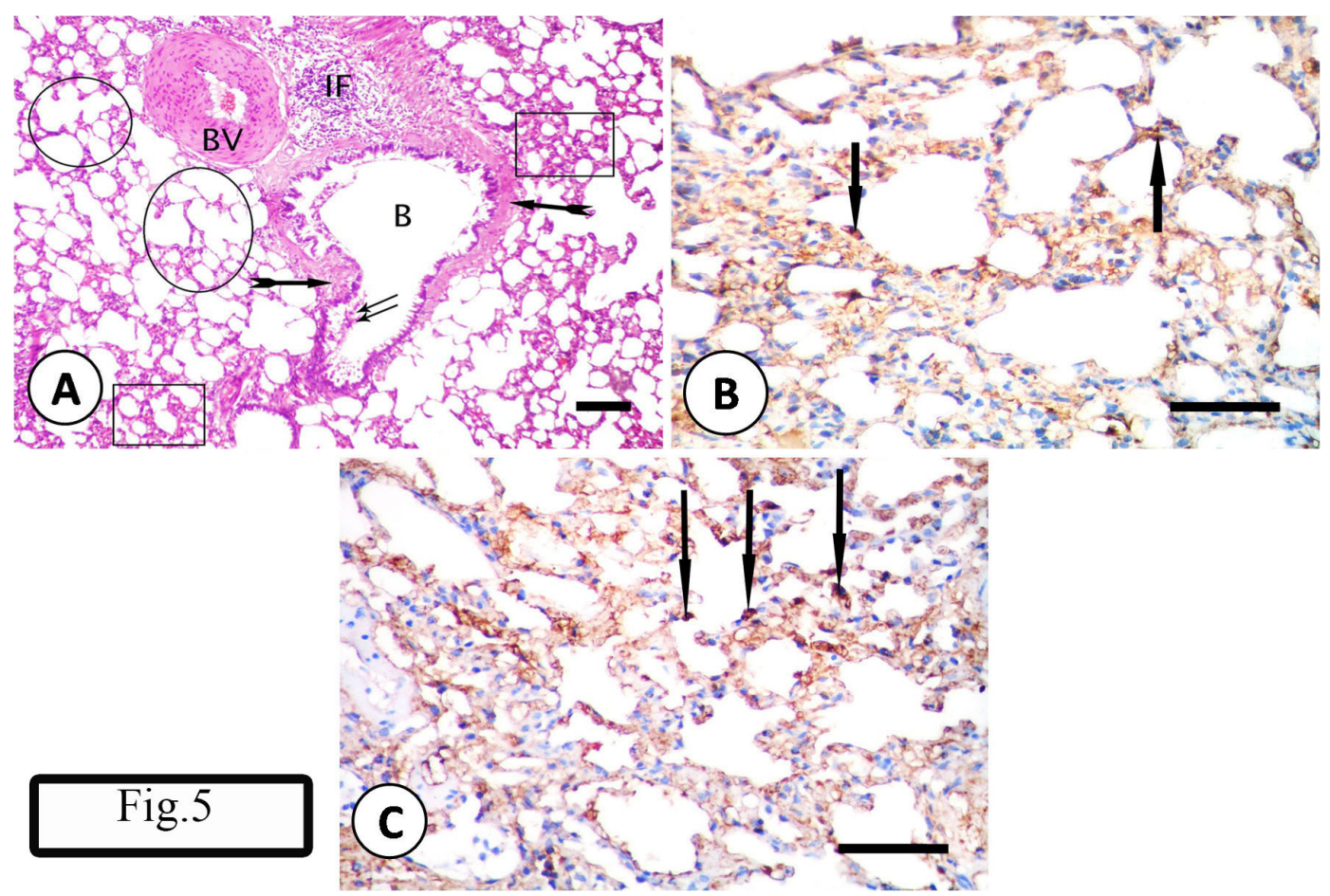

Fig. 5: A photomicrograph of sections in the lung from Ag-Nps recovery group. A) Focal areas of collapsed alveoli separated by thick interalveolar septa (square) and others are patent with thin inter-alveolar septa (circle). Bronchiole (B) with detached epithelial cells (double arrow), and smooth muscle layer (bifid arrow) is observed. Cellular infiltration (IF) is found mainly around the bronchiole (B) and around thickened wall blood vessel (BV) (H\&E, 100×, scale bar $50 \mu \mathrm{m})$. B) Moderate positive caspase-3 cytoplasmic immunoreaction in some alveolar epithelium and cells of inter alveolar septa (arrow) (Immune-staining for caspase-3 $\times 400$, Scale bar $40 \mu \mathrm{m}$ ). C) Moderate positive CD-68cytoplasmicimmunoreaction in cells of the inter-alveolar septa and in-between alveolar cells (arrow). (CD-68 immune-staining $\times 400$, Scale bar $40 \mu \mathrm{m})$.

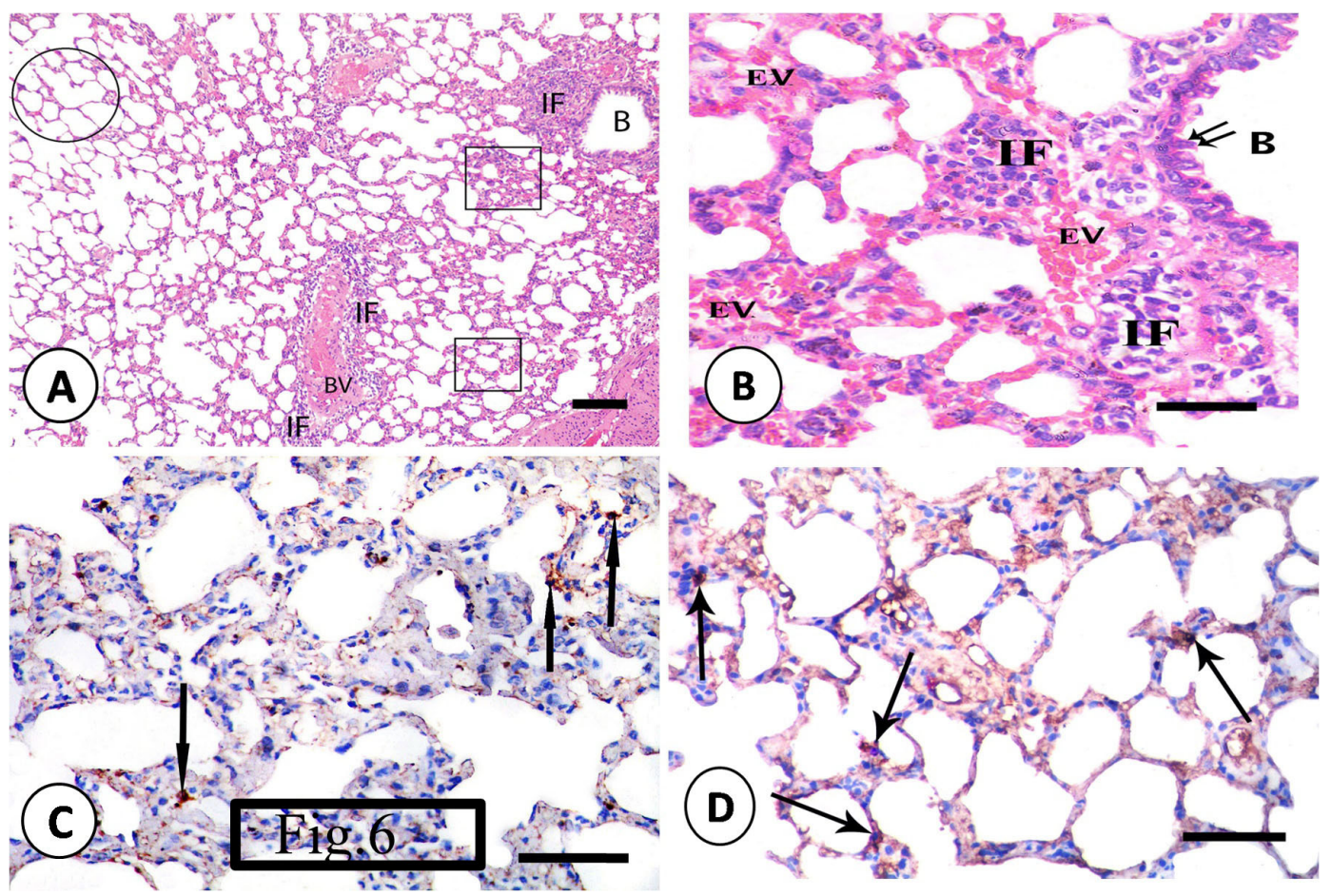

Fig. 6: A photomicrograph of sections in the lung of adult male albino rats of TiO2-Nps injected group. A) Most of alveoli are apparently normal with thin septa (circle) and few areas with thick septa (square) are detected. Mild cellular infiltration (IF) is seen mainly around blood vessel (BV) and bronchiole (B) (H\&E, x100, scale bar $50 \mu \mathrm{m})$. B) Areas of interstitial extravasation (EV). A terminal bronchiole (B) appears lined with simple cuboidal epithelium with no detachment (double arrows) and surrounded by cellular infiltration (IF) (H\&E, x400, scale bar $40 \mu \mathrm{m}$ ). C) Mild positive cytoplasmic immunoreaction for caspase-3 in some alveolar cells and interstitial cells (arrow) (Immune-staining for caspase $3 \times 400$, Scale bar $40 \mu \mathrm{m}$ ).D) Mild positive cytoplasmic immunoreaction for CD-68in some alveolar cells and in cells of inter alveolar septa (arrow) (CD-68 immune-staining $\times 400$, Scale bar $40 \mu \mathrm{m}$ ). 


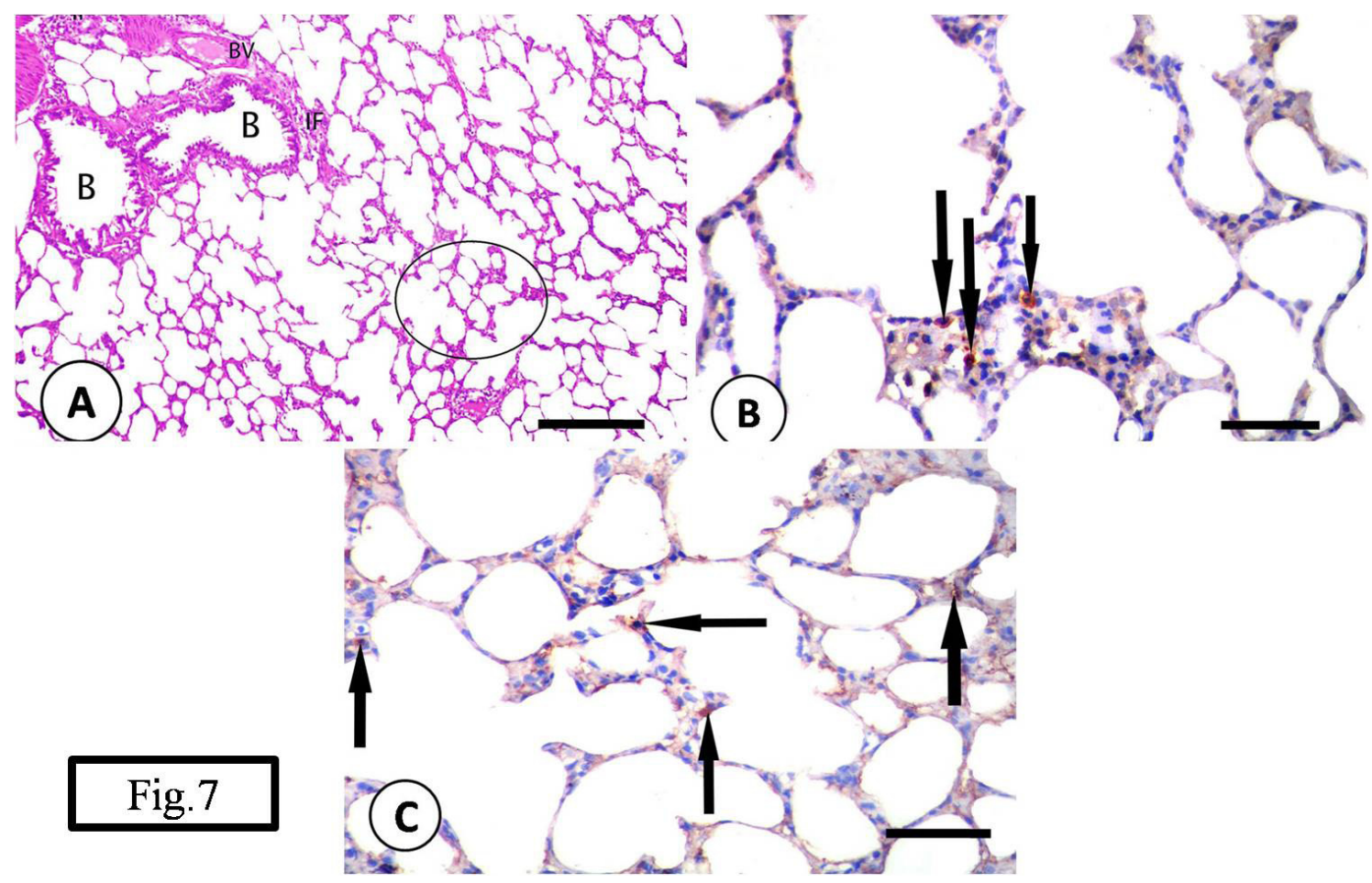

Fig. 7: A photomicrograph of sections in the lung fromTiO2-Nps recovery group. A) Most of alveoli are normal with thin inter-alveolar septa (circle). Minimal cellular infiltration (IF) is seen around Blood vessel (BV) and bronchiole (B) (H\&E, x100, scale bar $50 \mu \mathrm{m})$. B) Minimal positive cytoplasmic immunoreaction for caspase-3 in few alveolar epithelial cells and in few cells of interstitium (arrows) (Immune-staining for caspase- $3 \times 400$, Scale bar $40 \mu \mathrm{m})$ C) Minimal positive cytoplasmic immunoreaction for CD-68 in few alveolar epithelial cells and in few cells of inter alveolar septa (arrow) (CD-68 immune-staining $\times 400$, Scale bar $40 \mu \mathrm{m})$.

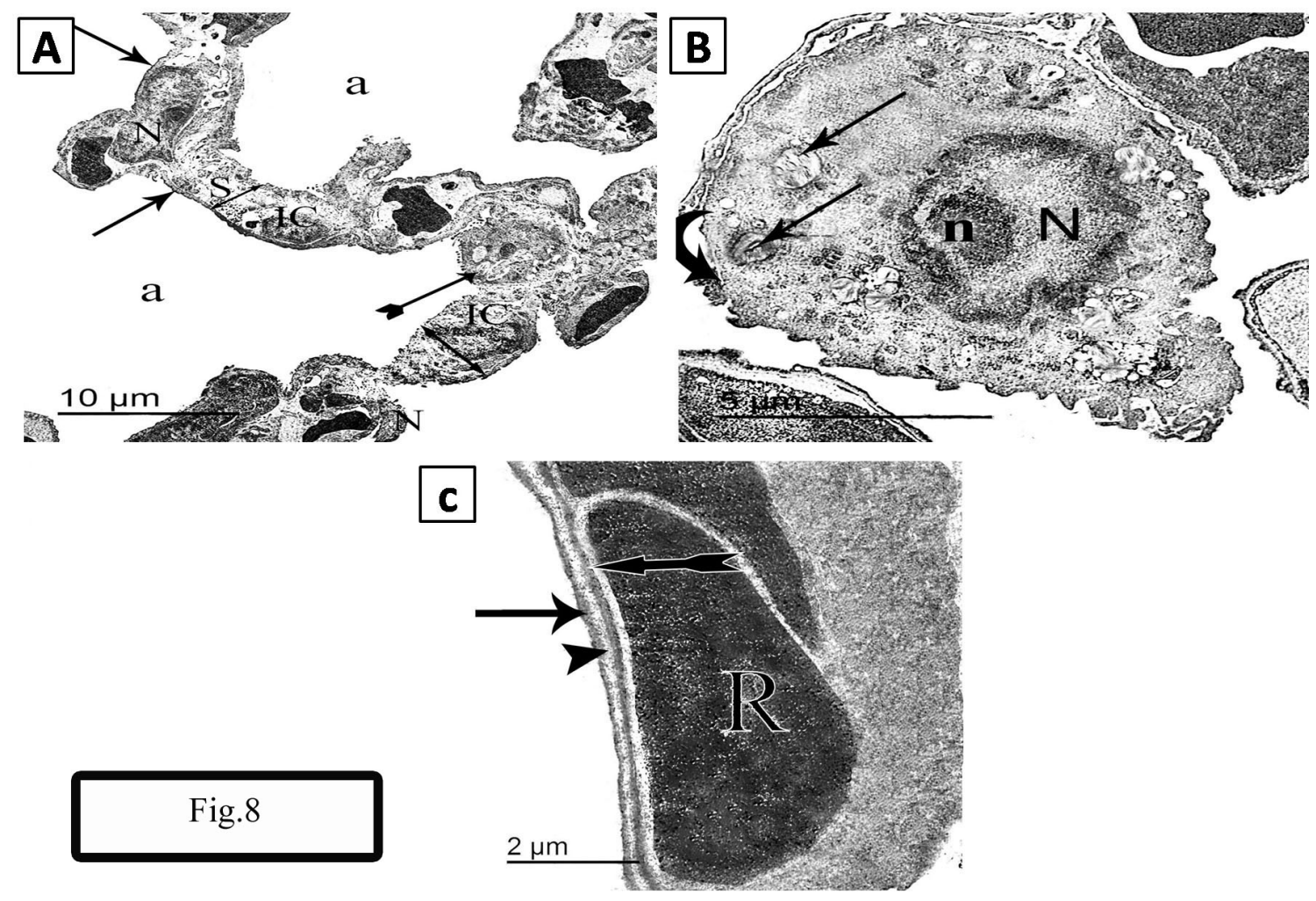

Fig. 8: An electron micrograph of sections in the lung from the control group. A) Alveoli (a) lined by pneumocytes type I with flat nucleus (N) with attenuated cytoplasm (thin arrow) and pneumocytes type II with lamellar bodies (bifid arrow). Thin inter-alveolar septum (S) containing interstitial cells (IC). (TEM X 3500). B) pneumocytes type II with euchromatic nucleus (N) and prominent nucleolus (n), well defined lamellar bodies (arrow). Microvilli (curved arrow) appear on its surface. (TEM X 10000). C) Blood-air barrier formed of attenuated cytoplasm of pneumocytes type I (arrow), fused basal lamina of pneumocyte type I and endothelial cell (arrow head) and cytoplasm of endothelial cell (bifid arrow) of alveolar capillary that contained red blood cells (R). (TEM X 15000). 

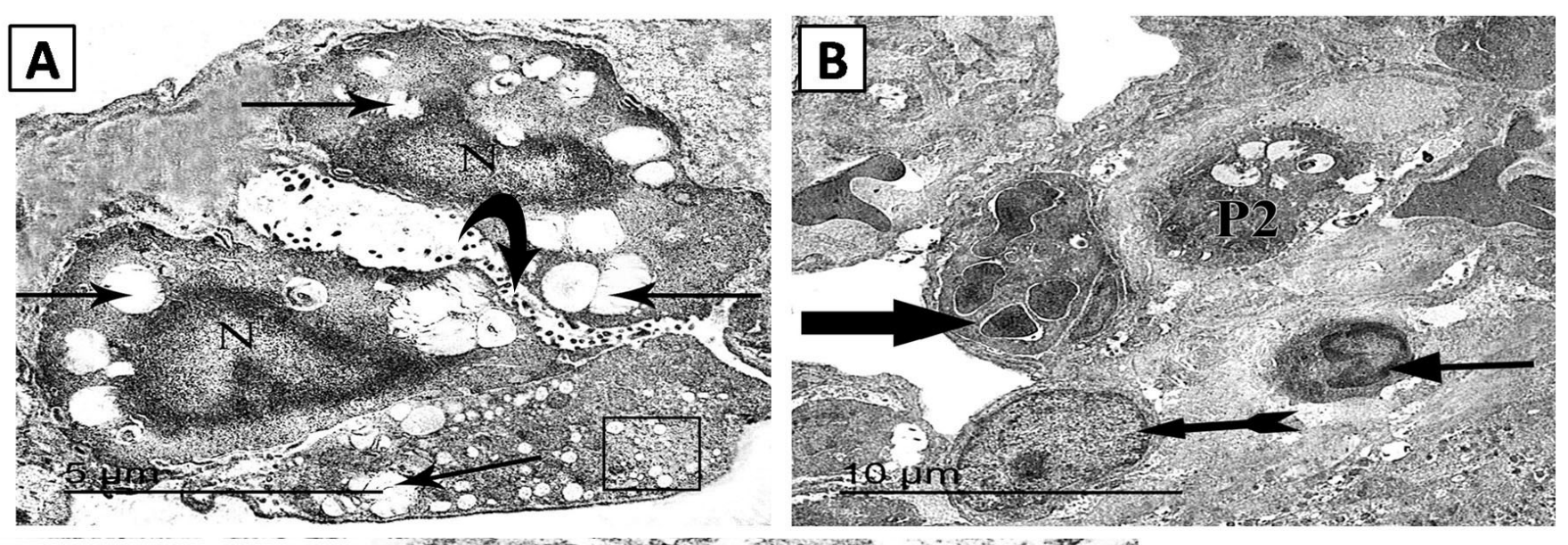

Fig.9

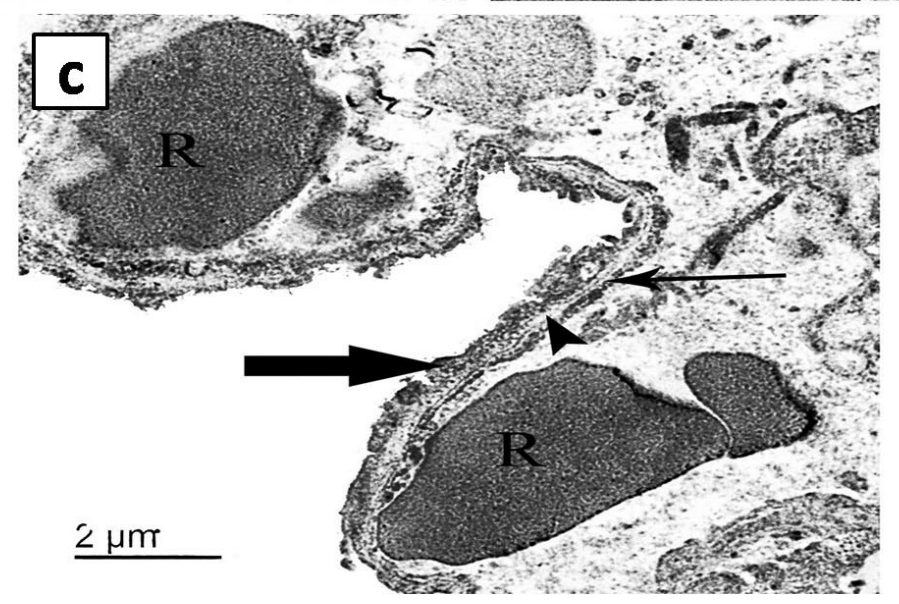

Fig. 9: An electron micrograph of sections in the lung from the Ag-Nps injected group. A) Multiple pneumocyte type II with irregular heterochromatic nuclei $(\mathrm{N})$, distorted lamellar bodies (arrow) and variable sized cytoplasmic vacuoles (square), and their microvilli (curved arrow) are seen on its surface. (TEM X 13000). B) Interstitium with different inflammatory cells; one of them has large kidney shaped nucleus (thin arrow), another with large euchromatic nucleus surrounded by thin rim of cytoplasm (bifid arrow). Cell with a lobulated nucleus within a blood capillary (thick arrow) and distorted pneumocyte type II (P2) are found. (TEM X 6000). C) Deformed blood air barrier, where cell membrane of pneumocytes type I (thick arrows) has irregularities, fused basal lamina of pneumocyte type I and endothelial cell (arrow head) and cytoplasm of endothelial cell (thin arrow) of alveolar capillary that contained red blood cells (R) are seen. (TEM X 17500). 

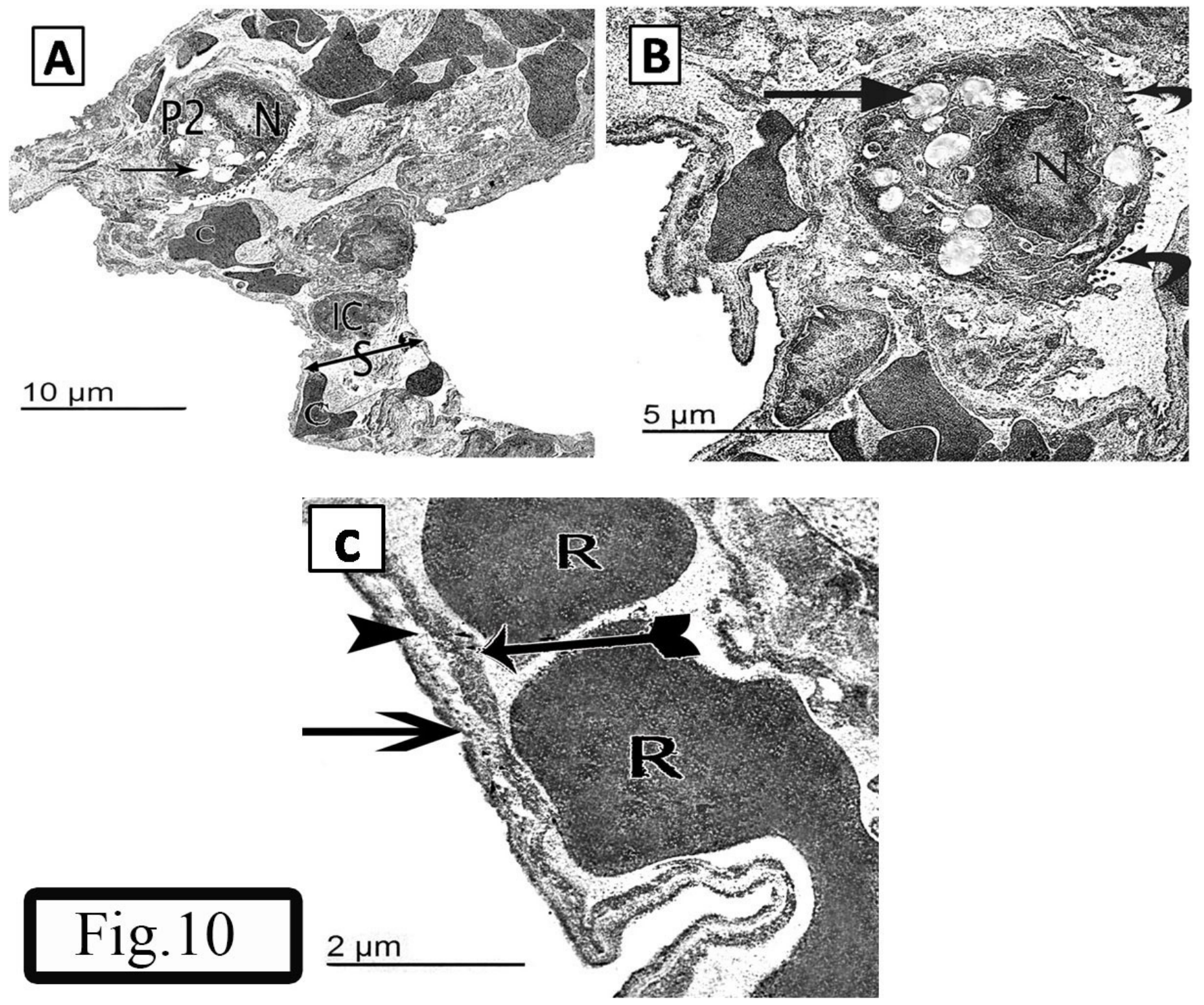

Fig. 10: An electron micrograph of sections in the from the Ag-Nps recovery group. A) Thick septa (S) containing interstisial cells (IC) and blood capillaries (C). Pneumocyte type II (P2) with heterochromatic nucleus (N) and exhibited loss of demarcation between nucleus and cytoplasm. Distorted lamellar bodies (arrow). (TEM X 4500). B) pneumocytes type II with heterochromatic nucleus (N) and some distorted lamellar bodies (arrow). Microvilli (curved arrow) appear on its surfaces. (TEM X 9000). C) Blood air barrier, where cell membrane of pneumocytes type I (thick arrow) has some irregularities, fused basal lamina of pneumocyte type I and endothelial cell (arrow head) and cytoplasm of endothelial cell (bifid arrow) of alveolar capillary that contained red blood cells (R).(TEM X 17500). 


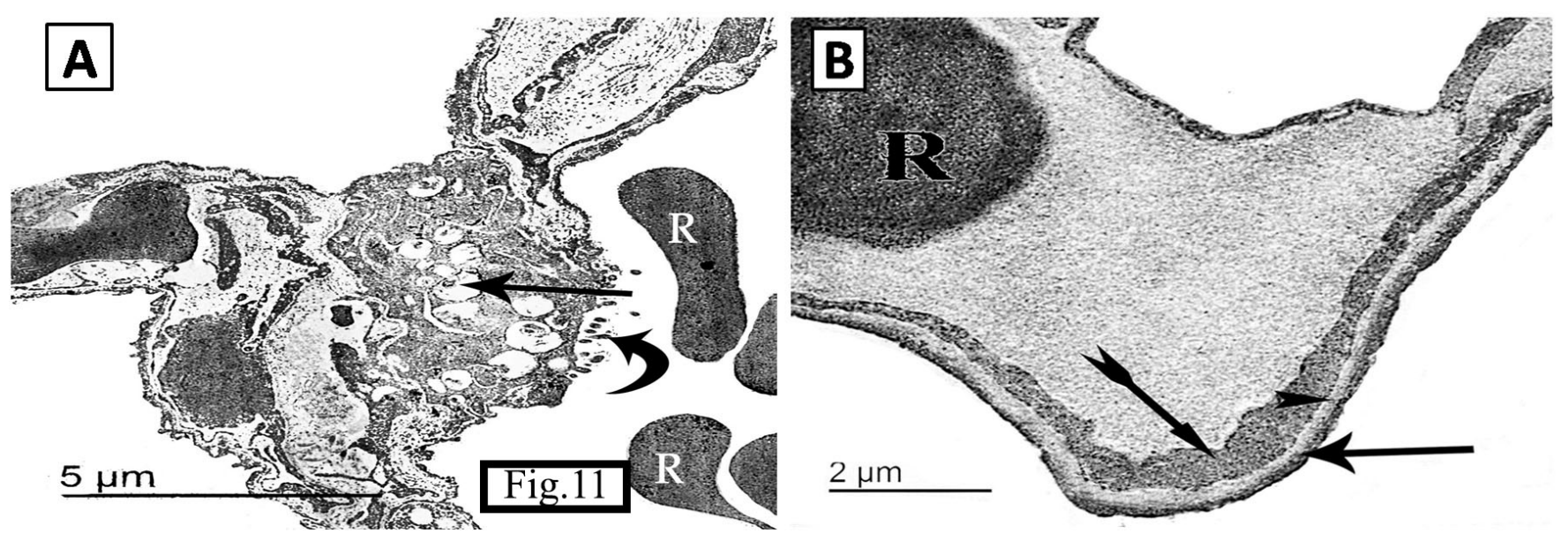

Fig. 11: An electron micrograph of sections in the lung from the TiO2-Nps injected group. A) apneumocyte type II with empty lamellar bodies (arrow) and microvilli (curved arrow) on its surface are seen . Intra-alveolar extravasation of red blood cells (R) is seen. (TEM X 12000). B) A nearly normal blood air barrier formed of type I pneumocyte attenuated cytoplasm (arrow), fused basal lamina (arrow head) of both cells (type I \& endothelium) and cytoplasm of the alveolar capillary (bifid arrow) that contain red blood cells (R). (TEM X 17500).

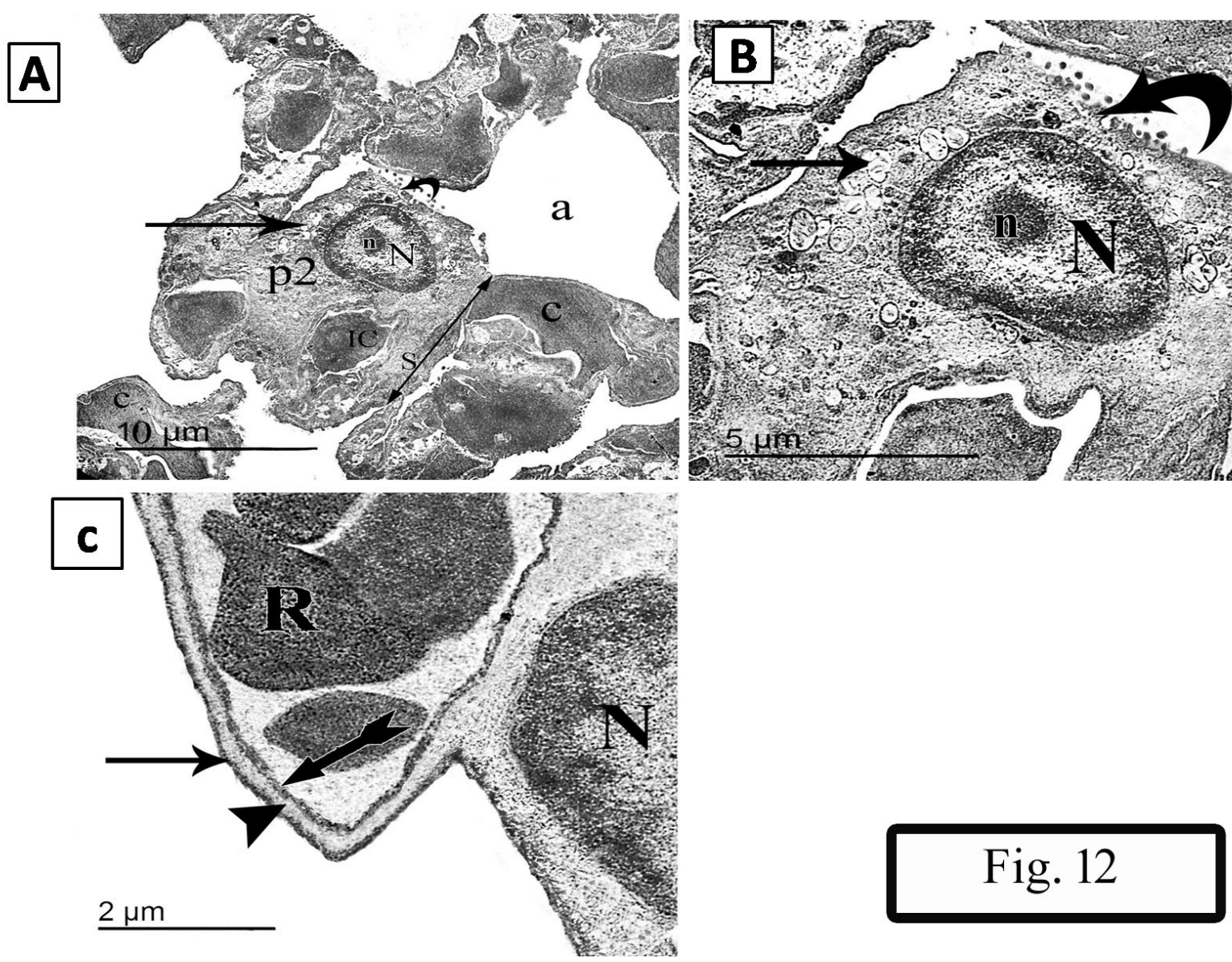

Fig. 12: An electron micrograph of sections in the lung from the TiO2-Nps recovery group. A\&B) Patent alveoli (a). Inter-alveolar septa (S) containing interstitial cells (IC) and blood capillaries (C) are detected. Pneumocyte type II (P2) appeared with euchromatic nucleus (N) and prominent nucleolus (n). Also, lamellar bodies (arrow) and microvilli (curved arrow) detected on its surface. (TEM X 4500) \& (TEM X 11000) respectively. C) A nearly normal blood air barrier formed of type I pneumocyte attenuated cytoplasm (arrow), fused basal lamina of pneumocyte type I and endothelial cell (arrow head) and cytoplasm of the capillary endothelial cell (bifid arrow) that contain red blood cell (R). Euchromatic nucleus of pneumocyte type I (N) is seen. (TEM X 20000). 


\section{DISCUSSION}

The emerging field of nano technology makes a new hope in treatment of cancer cells, industry and cosmetics production as nanoparticles have many advantages such as longer shelf-stability, high carrier capacity, and ability to incorporate hydrophilic and hydrophobic drug molecules increase the bioavailability of drugs. These drugs are targeted delivery at cellular and nuclear level ${ }^{[2]}$.

Meanwhile, unfortunately possible undesirable results and harmful interactions with biological systems and the environment may occur, with the potential to generate toxicity ${ }^{[41]}$.

Silver $(\mathrm{Ag})$ and titanium dioxide $(\mathrm{TiO} 2)$ nanoparticles are well-known nanoproducts. Both have common manufacturing applications such as in cosmetics, water filters, air conditioning filters and food industry. Medically they are both used as antifungal, antimicrobial and in treatment of cancer ${ }^{[19]}$

Many in vivo studies showed that nanoparticles can be accumulated in the liver, kidney, spleen, lung, heart and brain, whereby generating various inflammatory responses $^{[42]}$.

So, the present study was conducted to compare between the effect of silver nanoparticles and titanium dioxide nanoparticles on the lung and which one of them is safer.

In our work lung of Ag-Nps injected group was severely affected. H\&E stained sections showed many collapsed alveoli with thick inter alveolar septa, other alveoli showed ballooned distension. Previous authors mentioned similar results in silver nanoparticles treated lung ${ }^{[43,44]}$.

Alveolar collapse were supposed to be due to degeneration of type II pneumocytes which affect surfactant secretion leading to airway collapse and chronic obstructive pulmonary disease (COPD).This was documented previously regarding the pathogesis of such disease $^{[45]}$.

In this study we detect ballooned distension in the alveoli, which may be a compensatory pulmonary emphysema triggered by Nps activation of macrophages, up-regulations of inflammatory cytokines that resulted in disruption of alveolar septa, alveolar epithelial injury. This was stated withprevious research ${ }^{[46]}$.

On the other hand, light microscopic examination of TiO2-Nps injected rats showed moderate histological changes in the lung tissue compared to Ag-Nps injected group. Some alveoli were collapsed their interalveolar septa were thickened.
Previous researchers ${ }^{[47-51]}$ found similar changes in lung tissues in their studies and attributed these changes to free radicals produced by $\mathrm{TiO} 2-\mathrm{Nps}$, which exert a strong oxidizing abilityand produce epithelial injury and oxidative stress in rodents.

In agreement with previous authors ${ }^{[52]}$, thickened vessel wall with marked cellular infiltration were observed in the Ag-Nps injected lung. They proved that Ag-Nps induced pulmonary neutrophilic inflammation with the production of proinflammatory and pro-neutrophilic cytokines.

Lung sections of Ag-Nps group revealed marked cellular infiltration around bronchioles, blood vessels and in interstitium. On the other hand moderate cellular infiltrations were observed in $\mathrm{TiO} 2-\mathrm{Nps}$ injected group peri-bronchiolar and around blood vessels. Extravasation was also detected.

This observation was in agreement with previous researchers $^{[53,54]}$ who clarified that nanoparticles after entry into cells, lead to initiate inflammatory mechanisms, apoptosis and generate the oxygen free radicals which alter the functions of cells and affect oxidative metabolism of alveolar macrophages. Previous study ${ }^{[55]}$, stated that the inflammatory cellular influx is recruited from the circulation when local defenses are overwhelmed by injurious or toxic substances.

Macrophages play a critical role in clearance of both Ag-Nps and TiO2-Nps fromthe lung. Our data indicate increase macrophages in Ag-Nps injected group more than TiO2-Nps. These results were in accordance with previous researches ${ }^{[56-58]}$. These results confirmed statistically by a significant increase of the mean optical density of CD-68 in lung in comparison to the control group and $\mathrm{TiO} 2-\mathrm{Nps}$ injected group. It could be explained as a compensatory mechanism, as aside from responding to foreign particles (Nps) stimuli. As, alveolar macrophages are also involved in maintaining normal lung function ${ }^{[59]}$.

Cellular infiltrations and extravasation were documented with other researchers ${ }^{[60-62]}$ who explained that nanoparticles may affect permeability of the cell membranes and the endothelial lining of blood vessels leading to sequestration of inflammatory cells and red blood cells.

The key molecule vascular endothelium cadherin (VEcadherin) maintains endothelial cell-cell integrity. It was reported that the VE-cadherin was lost when endothelial cells were exposed with nanoparticles due to the direct combination of nanomaterials to VE-cadherin ${ }^{[63]}$. Through this mechanism, both Ag-Nps and TiO2-Nps leaking out of vessels through the membrane damage would attract immune cells in the peripheral tissue, causing inflammatory reactions. 
Another supposed mechanism is, Ag-Nps entering into the peripheral tissue can dissolve Ag ions, that resulting local high concentration of $\mathrm{Ag}$ ions that induce the oxidative damage on the membrane of cells, which induced inflammatory infiltration around the vessels ${ }^{[64,65]}$.

In addition TiO2-Nps injected group showed blood vessels injuries and hemorrhage that appeared in alveoli wall and alveolar space. Previous researches ${ }^{[18,51]}$ supposed that ROS could attach to the endothelial cells of vessel wall causing their damage and increase blood air barrier permeability, lead to extravasation into the septa.

Lung of Ag-Nps exposed rats exhibited vacuolation in epithelial cells of their bronchioles. These findings were in accordance with previous researchers ${ }^{[66]}$ who also observed vacuoles in the cytoplasm of Human Small Airway Epithelial Cells (SAEC).Other authors ${ }^{[67,68,69]}$ observed diffused vacuolated hepoatocytes after silver and gold Nps exposure. They attributed this vacuolation to cellular necrosis that caused impaired transport membrane activity, influx of sodium and water into the cell with resultant swelling of cells and organelles.

Ag-Nps have shown to be effective in triggering the activation of Caspase- 3 molecules resulting in the mediation and amplification of the death signal. Therefore, we examined the activities of caspase- 3 as a marker of apoptosis ${ }^{[70 \& 71]}$.

Extensive increase of caspase-3 activity after exposure to Ag-Nps was found in our study. These findings were confirmed statistically by a significant increase of the mean optical density of caspase- 3 in lung in comparison to the control group. And a significant increase of the mean optical density of caspase-3 in lung of Ag-Nps injected group in comparison to TiO2-Nps injected group. In regard to apoptotic cell death.

Reactive oxygen species (ROS) generation and oxidative stress appear to be likely the mechanism of both Ag-Nps and TiO2-Nps toxicity ${ }^{[72-74]}$.

Hoet et $a{ }^{[75]}$ claimed that regression of antioxidant defense responses and/or generation of free radicals due to oxidative stress may result after exposure to different Nps. Pulmonary response to oxidative stress generated by both Ag-Nps and TiO2-Nps is due to either the direct effect of the particles themselves or an indirect effect of the inflammatory reaction ${ }^{[76,77]}$.

Ultrastructural examination of the lung of $\mathrm{Ag}-\mathrm{Nps}$ exposed rats revealed pneumocytes type II with irregular heterochromatic nuclei and vacuolated cytoplasm with empty or irregular lamellar bodies. Vacuolated cytoplasm was also detected previously in hepatic cells of both rats and mice ${ }^{[78,79]}$.
Previous authors ${ }^{[80]}$ attributed this vacuolation to the effects of excessive free radicals on the cell membrane that facilitate the release of lysosomal enzymes into the cytosol causing cellular fragmentation and vacuolations. Also increased osmotic fragility and inactivation of membrane bound enzymes such as ATPase that leads to swelling of cytoplasmic membranous components caused by intracellular water and electrolytes redistribution. In accordance to previous authors ${ }^{[81]}$, the empty lamellar bodies caused by lipid peroxidation of membrane phospholipids with an impairment of surfactant secretion and turnover.

Whereas, ultra-structural examination of $\mathrm{TiO} 2-\mathrm{Nps}$ group revealed pneumocyte type II with empty lamellar bodies and microvilli on its surface. Multiple red blood cells are detected in the alveolar space; these results were in agreement with other researchers ${ }^{[52]}$.

After 4 weeks without any treatment to both (AgNps and TiO2-Nps) injected groups; different degrees of improvement in the histological structure of the lung has been observed.

Recovery group of Ag-Nps showed slight improvement in some sections. They revealed focal areas of collapsed alveoli separated by thick inter-alveolar septa and other were patent with thin inter-alveolar septa. Bronchiole appeared with detached epithelium. Also, thickened wall blood vessels were clarified with cellular infiltrations around both blood vessels and bronchiole.

These results also confirmed by previous authors ${ }^{[33]}$ who detect Ag-Nps concentrations in the treated group were not completely cleared from lung samples after 12-week recovery period, although these Ag-Nps concentrations cleared gradually from the lung tissue.

Recovery group of TiO2-Nps showed marked improvement or apparently normal histological architecture. They revealed that most of alveoli were normal with thin inter-alveolar septa. Minimal cellular infiltration around blood vessel and bronchiole were detected. Previous authors ${ }^{[35]}$ detected the same finding.

Our previous results lead us to conclude that $\mathrm{TiO} 2-$ Nps more save than Ag-Nps. Similar to Asare et al ${ }^{[82]}$ who stated that Ag-Nps are more cytotoxic compared to $\mathrm{TiO} 2-\mathrm{Nps}$, causing apoptosis, necrosis and decreased proliferation in a concentration- and time-dependent manner.

These findings of recovery groups were confirmed statistically by a significant increase in the thickness of inter alveolar septa and the mean optical density of caspase-3 and CD-68 in lung of Ag-Nps recovery group in comparison to the $\mathrm{TiO} 2-\mathrm{Nps}$ recovery group. 
In conclusion, exposure to Ag-Nps for a long time showed marked alterations on histological structure of lung tissue, which was more injurious than TiO2-Nps.In addition, recovery period was proved to ameliorate these changes better in $\mathrm{TiO} 2-\mathrm{Nps}$.

Therefore, manufacturers should be aware that there may be additional safety considerations for Ag-Nps containing products to decrease exposure to it.

So, we recommend using $\mathrm{TiO} 2-\mathrm{Nps}$ in cosmetics and industrial substances. Finally, further in vivo experimental and clinical research regarding comparison between the effect of TiO2-Nps and Ag-Nps is also recommended

\section{ACKNOWLEDGEMENTS:}

Not applicable

\section{CONFLICT OF INTEREST:}

The authors declared that there is no conflict of interest.

\section{FUNDING:}

No funding was received. The research was self-funded by the authors.

\section{REFERENCES:}

1. Formoso P, Muzzalupo R, Tavano L, De Filpo G, Pasquale Nicoletta F. Nanotechnology for the environment and medicine. Mini Reviews in Medicinal Chemistry 2016; 16(8): 668-675.

2. Sironmani A, Daniel K. Silver nanoparticlesuniversal multifunctional nanoparticles for bio sensing, imaging for diagnostics and targeted drug delivery for therapeutic applications. In Drug Discovery and Development-Present and Future. In Tech. 2011

3. Elkhawass EA, Mohallal ME, Soliman MFM. Acute toxicity of different sizes of silver nanoparticles intraperitonally injected in Balb/C mice using two toxicological methods. Int J Pharm Pharm Sci 2015; 7(2), 94-99.

4. Ault AP, Stark DI, Axson JL, Keeney JN, Maynard AD, Bergin IL, Philbert MA. Protein corona-induced modification of silver nanoparticle aggregation in simulated gastric fluid. Environmental Science: Nano 2016; 3(6): 1510-1520.
5. Helmlinger J, Sengstock C, Gross-Heitfeld C, Mayer C, Schildhauer TA, Köller M, Epple M. Silver nanoparticles with different size and shape: equal cytotoxicity, but different antibacterial effects. RSC Advances 2016; 6(22): 18490-18501.

6. Zhang $\mathrm{C}, \mathrm{Hu} \mathrm{Z}$, Deng B. Silver nanoparticles in aquatic environments: Physiochemical behavior and antimicrobial mechanisms. Water Research 2016; 88: 403-427.

7. Singh S, Patel P, Jaiswal S, Prabhune AA, Ramana CV, Prasad BLV. A direct method for the preparation of glycolipid-metal nanoparticle conjugates: sophorolipids as reducing and capping agents for the synthesis of water re-dispersible silver nanoparticles and their antibacterial activity. New Journal of Chemistry 2009; 33(3): 646-652.

8. Seabra AB, and Durán N. Nitric oxide-releasing vehicles for biomedical applications. Journal of Materials Chemistry 2010; 20(9): 1624-1637.

9. Wong KK, Liu X. Silver nanoparticles-the real "silver bullet" in clinical medicine?. Med Chem Comm 2010; 1(2): 125-131

10. Schluesener JK, Schluesener HJ. Nanosilver: application and novel aspects of toxicology. Archives of Toxicology 2013; 87(4): 569-576.

11. Shi H, Magaye R, Castranova V, Zhao J. Titanium dioxide nanoparticles: a review of current toxicological data. Particle and Fibre Toxicology 2013; 10(1): 15 .

12. Salthammer T, Fuhrmann F. Photocatalytic surface reactions on indoor wall paint. Environmental Science \& Technology 2007; 41(18): 6573-6578.

13. Gupta SM, Tripathi M. A review of TiO 2 nanoparticles. Chinese Science Bulletin 2011; 56(16): 1639.

14. Li JJE, Muralikrishnan S, Ng, CT, Yung LYL, and Bay BH. Nanoparticle induced pulmonary toxicity. Experimental Biology and Medicine 2012; 235(9): 1025-1033

15. Kang CG, Park YB, Choi H, Oh S, Lee KW, Choi SH, Shim JS. Osseointegration of implants surfacetreated with various diameters of $\mathrm{TiO} 2$ nanotubes in rabbit. Journal of Nanomaterials 2015; 3. 
16. Murugan K, Dinesh D, Kavithaa K, Paulpandi M, Ponraj T, Alsalhi MS, Kumar S. Hydrothermal synthesis of titanium dioxide nanoparticles: mosquitocidal potential and anticancer activity on human breast cancer cells (MCF-7). Parasitology Research 2016; 115(3): 1085-1096.

17. Wang JX, Zhou GQ, Chen CY, Yu HW, Wang TC, Ma YM. Acute toxicity and biodistribution of different sized titanium dioxide particles in mice after oral administration. Toxicol Lett 2007; 168: 176-185.

18. Mohammadi F, Sadeghi L, Mohammadi A, Tanwir F, Yousefi VB, Izadnejad M. The effects of Nano titanium dioxide (TiO2NPs) on lung tissue. Bratislavske Lekarske Listy 2015; 116(6): 363367.

19. Ganapathi AP, Devaki R, Thuniki NR, Manna J, Tirumuru B, Gopu CR, Hasan A. In vitro assessment of $\mathrm{Ag}$ and $\mathrm{TiO} 2$ nanoparticles cytotoxicity. International Journal of Research in Medical Sciences 2017; 2(4): 1360-1367.

20. Panda KK, Achary VMM, Krishnaveni R, Padhi BK, Sarangi SN, Sahu SN, Panda BB. In vitro biosynthesis and genotoxicity bioassay of silver nanoparticles using plants. Toxicology in vitro 2011; 25(5): 1097-1105.

21. Gaiser BK, Fernandes TF, Jepson MA, Lead JR, Tyler CR, Baalousha M, Ju-Nam Y. Interspecies comparisons on the uptake and toxicity of silver and cerium dioxide nanoparticles. Environmental Toxicology and Chemistry 2012; 31(1): 144-154.

22. Blaser SA, Scheringer $M$, MacLeod $M$, Hungerbühler K. Estimation of cumulative aquatic exposure and risk due to silver: contribution of nano-functionalized plastics and textiles. Science of the Total Environment 2008; 390(2-3): 396-409.

23. Mueller NC, Nowack B. Exposure modeling of engineered nanoparticles in the environment. Environmental Science and Technology 2008; 42(12): 4447-4453.

24. Hong JS, Kim S, Lee SH, Jo E, Lee B, Yoon J, Lee MY. Combined repeated-dose toxicity study of silver nanoparticles with the reproduction/ developmental toxicity screening test. Nanotoxicology 2014; 8(4): 349-362.
25. Johnston HJ, Hutchison G, Christensen FM, Peters $\mathrm{S}$, Hankin S, Stone V. A review of the in vivo and in vitro toxicity of silver and gold particulates: particle attributes and biological mechanisms responsible for the observed toxicity. Critical Reviews in Toxicology 2010; 40(4): 328-346.

26. Yin N, Liu Q, Liu J, He B, Cui L, Li Z, Jiang G. Silver nanoparticle exposure attenuates the viability of rat cerebellum granule cells through apoptosis coupled to oxidative stress. Small 2013 9(9\&10): 1831-1841.

27. Makumire S, Chakravadhanula VSK, Köllisch G, Redel E, Shonhai A. Immunomodulatory activity of zinc peroxide $(\mathrm{ZnO} 2)$ and titanium dioxide (TiO2) nanoparticles and their effects on DNA and protein integrity. Toxicology Letters 2014; 227 : 56-64.

28. Antony JJ, Sivalingam P, Chen B. Toxicological effects of silver nanoparticles. Environmental Toxicology and Pharmacology 2015; 40(3): 729732

29. Sharmila Devi R, Venckatesh R, Sivaraj R. Synthesis of titanium dioxide nanoparticles by solgel technique. International journal of innovative research in science, Engineers and Technology 2014; 3(8): 15206-15211.

30. Lee JH, Kim YS, Song KS, Ryu HR, Sung JH, Park JD et al. Biopersistence of silver nanoparticles in tissues from Sprague Dawley rats. Part Fibre Toxicol 2013; 10: 36.

31. Amin Y, Hawas A, El-Batal A, Hassan S, Elsayed M. Evaluation of Acute and Subchronic Toxicity of Silver Nanoparticles in Normal and Irradiated Animals. Br J Pharmacol Toxicol 2015; 6(2):2238 .

32. Ahmed SM, Abdelrahman SA, Shalaby SM. Evaluating the effect of silver nanoparticles on testes of adult albino rats (histological, immunohisto-chemical and biochemical study). Journal of Molecular Histology 2017; 48(1): 9-27.

33. Song KS, Sung JH, Ji JH, Lee JH, Lee JS, Ryu HR, Chang HK. Recovery from silvernanoparticle-exposure-induced lung inflammation and lung function changes in Sprague Dawley rats. Nanotoxicology 2013; 7(2): 169-180. 
34. Helmy AM, Sharaf-El-Din NA, Abd-El-Moneim RA, Rostom DM. Histological study of the renal cortical proximal and distal tubules in adult male albino rats following prolonged administration of titanium dioxide nanoparticles and the possible protective role of 1-carnosine. Egyptian Journal of Histology 2015; 38(1): 126-142.

35. Kobayashi N, Naya M, Endoh S, Maru J, Yamamoto K, Nakanishi J. Comparative pulmonary toxicity study of nano-TiO2 particles of different sizes and agglomerations in rats: different short-and longterm post-instillation results. Toxicology 2009; 264(1-2): 110-118.

36. Wen L, Gao Q, Wah Ma C, et al. Effect of polysaccharides from Tremella fuciformis on UVinduced photoaging. Journal of Functional Foods 2016; 20: 400-410.

37. Bancroft J, and Gamble A. A Theory and Practice of Histological Techniques 6th ed. Chuchil Livingstone, New York, London 2008; 165-175.

38. Cattoretti G, Pileri S, Parravicini C, Becker $\mathrm{MH}$, Poggi S, Bifulco C, Reynolds F. Antigen unmasking on formalin fixed, paraffin embedded tissue sections. The Journal of Pathology 1993; 171(2): 83-98

39. Kiernan JA.. Histological and histochemical methods: theory and practice. Shock 1999; 12(6): 479.

40. Hayat MA. Principles and Techniques of Electron Microscopy: Biological Applications. Cambridge: Cambridge Univ Press 4, 2000; 546-558.

41. Surendiran A, Sandhiya S, Pradhan SC, Adithan C. Novel applications of nanotechnology in medicine. Indian Journal of Medical Research 2009; 130(6).

42. Brown JS, Zeman KL, Bennett WD. Ultrafine particle deposition and clearance in the healthy and obstructed lung. American Journal of Respiratory and Critical Care Medicine 2002;, 166(9): 12401247.

43. Stebounova LV, Adamcakova-Dodd A, Kim JS, Park HT, O'Shaughnessy P, Grassian VH, Thorne PS. Nanosilver induces minimal lung toxicity or inflammation in a subacute murine inhalation model. Particle and Fibre Toxicology 2011; 8(1), 5.

44. Moradi-Sardareh H, Basir HRG, Hassan ZM, Davoudi M, Amidi F, Paknejad M. Toxicity of silver nanoparticles on different tissues of $\mathrm{Balb} / \mathrm{C}$ mice. Life Sciences 2018; 211: 81-90.
45. Zhao CZ, Fang XC, Wang D, Tang FD, Wang $\mathrm{XD}$ : Involvement of type II pneumocytes in the pathogenesis of chronic obstructive pulmonary disease. Respiratory Medicine 2010; 104(10): 1391-1395.

46. Chen HW, Su SF, Chien CT, Lin WH, Yu SL, Chou CC, Chien CT. Titanium dioxide nanoparticles induce emphysema-like lung injury in mice. The FASEB Journal 2006; 20(13): 2393 2395 .

47. Monteiller C, Tran L, MacNee W, Faux S, Jones A, Miller B, Donaldson K. The pro-inflammatory effects of low-toxicity low-solubility particles, nanoparticles and fine particles, on epithelial cells in vitro: the role of surface area. Occupational and Environmental Medicine 2007; 64(9): 609615 .

48. Sun Q, Tan D, Zhou Q, Liu X, Cheng Z, Liu $\mathrm{G}, \mathrm{Hu} \mathrm{R}$. Oxidative damage of lung and its protective mechanism in mice caused by long term exposure to titanium dioxide nanoparticles. Journal of biomedical materials research Part A 2012; 100(10): 2554-2562.

49. Li B, Ze Y, Sun Q, Zhang T, Sang X, Cui Y, Zhao $X$. Molecular mechanisms of nanosized titanium dioxide-Induced pulmonary injury in mice. PloS one 2013 ; 8(2): e55563.

50. Xu J, Shi H, Ruth M, Yu H, Lazar L, Zou B, Zhao J. Acute toxicity of intravenously administered titanium dioxide nanoparticles in mice. PloS one 2013; 8(8): e70618.

51. El-Haliem NGA. The possible role of milk thistle extract on titanium dioxide nanoparticles-induced lung toxicity in male albino rat: a histological and immunohistochemical study. Egyptian Journal of Histology 2016; 39(2): 179-190.

52. Seiffert J, Buckley A, Leo B, Martin NG, Zhu J, Dai R, Gong J. Pulmonary effects of inhalation of spark-generated silver nanoparticles in BrownNorway and Sprague-Dawley rats. Respiratory Research 2016; 17(1): 85.

53. Grande F, Tucci P. Titanium dioxide nanoparticles: a risk for human health?. Mini Reviews in Medicinal Chemistry 2016; 16(9): 762-769.

54. Fartkhooni FM, Noori A, Mohammadi A. Effects of titanium dioxide nanoparticles toxicity on the kidney of male rats. International Journal of Life Sciences 2016; 10(1): 65-69. 
55. Grommes J, Soehnlein O. Contribution of neutrophils to acute lung injury. Mol Med; 17(34): 293.

56. Grassian VH, O'shaughnessy PT, AdamcakovaDodd A, Pettibone JM, Thorne PS. Inhalation exposure study of titanium dioxide nanoparticles with a primary particle size of 2 to $5 \mathrm{~nm}$. Environ. Health Perspect 2007; 115 (3): 397-402.

57. Silva RM, TeeSy C, Franzi L, Weir A, Westerhoff $\mathrm{P}$, Evans JE, Pinkerton, KE. Biological response to nano-scale titanium dioxide ( $\mathrm{TiO} 2)$ : role of particle dose, shape, and retention. Journal of Toxicology and Environmental Health, Part A 2013; 76(16): 953-972.

58. Anderson DS, Silva RM, Lee D, Edwards PC, Sharmah A, Guo T, Van Winkle LS. Persistence of silver nanoparticles in the rat lung: Influence of dose, size, and chemical composition. Nanotoxicology 2015; 9(5): 591-602.

59. Ahmed SM, Abdelrahman SA, Shalaby SM. Evaluating the effect of silver nanoparticles on testes of adult albino rats (histological, immunehistochemical and biochemical study). Journal of Molecular Histology; 48(1): 9-27.

60. Donaldson K, Stone V, Seaton A, MacNee W. Ambient particle inhalation and the cardiovascular system: potential mechanisms. Environmental Health Perspectives; 109 (Suppl 4): 523.

61. Duan Y, Liu J, Ma L, Li N, Liu H, Wang J, Yan J. Toxicological characteristics of nanoparticulate anatase titanium dioxide in mice. Biomaterials 2010; 31(5): 894-899.

62. Alarifi S, Ali D, Al-Doaiss AA, Ali BA, Ahmed M, Al-Khedhairy AA. Histologic and apoptotic changes induced by titanium dioxide nanoparticles in the livers of rats. International Journal of Nanomedicine 2013; 8: 3937.

63. Setyawati MI, Tay CY, Chia SL, Goh SL, Fang W, Neo MJ, Xie JP. Titanium dioxide nanomaterials cause endothelial cell leakiness by disrupting the homophilic interaction of VE-cadherin. Nature Communications 2013; 4: 1673.

64. Meng J, Ji Y, Liu J, Cheng X, Guo H, Zhang $\mathrm{W}, \mathrm{Xu} \mathrm{H}$. Using gold nanorods core/silver shell nanostructures as model material to probe biodistribution and toxic effects of silver nanoparticles in mice. Nanotoxicology 2014; 8(6): 686-696.
65. Guo H, Zhang J, Boudreau M, Meng J, Yin $\mathrm{JJ}$, Liu $\mathrm{J}, \mathrm{Xu} \mathrm{H}$. Intravenous administration of silver nanoparticles causes organ toxicity through intracellular ROS-related loss of inter-endothelial junction. Particle and Fibre Toxicology 2015; 13(1): 21.

66. Li JJE, Muralikrishnan S, Ng CT, Yung LYL, Bay BH. Nanoparticle-induced pulmonary toxicity. Experimental Biology and Medicine 2010; 235(9): 1025-1033.

67. Yousef J, Hendi H, Hakami FS, Awad MA, Alem AF, Hendi AA, Al-Mrshoud MF. Toxicity of silver nanoparticles after Injected intraperitoneally in rats. J Am Sci, 8(3): 589593.

68. Wu Y, Zhou Q. Silver nanoparticles cause oxidative damage and histological changes in medaka (Oryzias latipes) after 14 days of exposure. Environmental Toxicology and Chemistry 2013; 32(1): 165-173.

69. Abdelhalim MAK, Jarrar BM. Gold nanoparticles induced cloudy swelling to hydropic degeneration, cytoplasmic hyaline vacuolation, polymorphism, binucleation, karyopyknosis, karyolysis, karyorrhexis and necrosis in the liver. Lipids in Health and Disease 2011; 10(1): 166.

70. Li J, Yuan J. Caspases in apoptosis and beyond. Oncogene 2008; 27(48): 6194.

71. Moaddab S, Ahari H, Shahbazzadeh D, Motallebi A, Anvar A, Rahman-Nya J, Shokrgozar M. Toxicity Study of Nanosilver (Nanocid) on Osteoblast Cancer Cell Line. Int Nano Lett 2011; 1(1):11-16

72. Nel A, Xia T, Mädler L, Li N. Toxic potential of materials at the nanolevel. Science 2006; 311(5761): 622-627.

73. Kang SJ, Kim BM, Lee YJ, Hong SH, Chung HW. Titanium dioxide nanoparticles induce apoptosis through the $\mathrm{JNK} / \mathrm{p} 38$-caspase-8-Bid pathway in phytohemagglutinin-stimulated human lymphocytes. Biochemical and Biophysical Research Communications 2009; 386(4), 682-687.

74. Liu J, Sonshine DA, Shervani S, Hurt RH. Controlled release of biologically active silver from nanosilver surfaces. ACS Nano 2010; 4(11): 6903-6913. 
75. Hoet PH, Brüske-Hohlfeld I, Salata OV. Nanoparticles-known and unknown health risks. Journal of Nanobiotechnology 2004; 2(1): 12.

76. Huang CJ, Webb HE, Evans RK, McCleod KA, Tangsilsat SE. Psychological stress during exercise: immune-endocrine and oxidative responses. Experimental Biology and Medicine 2010; 235(12): 1498-1504.

77. Kaewamatawong $\mathrm{T}$, Banlunara $\mathrm{W}$, Maneewattanapinyo $\mathrm{P}$, Thammacharoen $\mathrm{C}$, Ekgasit S. Acute pulmonary toxicity caused by single intratracheal instillation of various doses of colloidal silver nanoparticles in mice: Pathological changes, particle bioaccumulation and metallothionien protein expression. The Thai Journal of Veterinary Medicine 2013; 43(3): 383.

78. Patlolla AK, Hackett D, Tchounwou PB. Silver nanoparticle-induced oxidative stress-dependent toxicity in Sprague-Dawley rats. Molecular and cellular biochemistry 2015; 399(1-2): 257-268.
79. Cho YM, Mizuta Y, Akagi JI, Toyoda T, Sone M, Ogawa K. Size-dependent acute toxicity of silver nanoparticles in mice. Journal of Toxicologic Pathology; 31(1): 73-80.

80. Tokunaga T, Morshed S, Otsuki S, Takayama F, Satoh T, Hashimoto K, Yasui T, Ogawa S, Kanegae $\mathrm{H}$, Yokote Y, et al. Effect of antioxidants, oxidants, metals and saliva on cytotoxicity induction by sodium fluoride. Anticancer Research 2003; 23(5): 3719-3726.

81. Lawson W E, Crossno PF, Polosukhin V V, Roldan J, Cheng DS, Lane K. Endoplasmic reticulum stress in alveolar epithelial cells is prominent in IPF: association with altered surfactant protein processing and herpesvirus infection. Am J Physiol Lung Cell Mol Physiol 2008; 294(6): 1119-1126.

82. Asare N, Instanes C, Sandberg WJ, Refsnes M, Schwarze P, Kruszewski M, Brunborg G. Cytotoxic and genotoxic effects of silver nanoparticles in testicular cells. Toxicology 2012; 291(1):65-72. 